Review

\title{
Biological and Pharmacological Effects of Synthetic Saponins
}

\author{
Yu-Pu Juang and Pi-Hui Liang *(1) \\ School of Pharmacy, College of Medicine, National Taiwan University, Taipei 100, Taiwan; a98754687@gmail.com \\ * Correspondence: phliang@ntu.edu.tw
}

Academic Editor: David Popovich

check for

Received: 30 September 2020; Accepted: 25 October 2020; Published: 27 October 2020

\begin{abstract}
Saponins are amphiphilic molecules consisting of carbohydrate and either triterpenoid or steroid aglycone moieties and are noted for their multiple biological activities-Fungicidal, antimicrobial, antiviral, anti-inflammatory, anticancer, antioxidant and immunomodulatory effects have all been observed. Saponins from natural sources have long been used in herbal and traditional medicines; however, the isolation of complexed saponins from nature is difficult and laborious, due to the scarce amount and structure heterogeneity. Chemical synthesis is considered a powerful tool to expand the structural diversity of saponin, leading to the discovery of promising compounds. This review focuses on recent developments in the structure optimization and biological evaluation of synthetic triterpenoid and steroid saponin derivatives. By summarizing the structure-activity relationship (SAR) results, we hope to provide the direction for future development of saponin-based bioactive compounds.
\end{abstract}

Keywords: synthetic saponins; triterpenoid saponins; steroid saponins; bioactivity; mechanism

\section{Introduction}

The name "saponin" is derived from the Latin word sapo, meaning soap-like foam-generating ability, and the amphiphilic properties derived from the structure containing an isoprenoid-derived aglycone (a sapogenin) attached to one or more sugar chains by either an ether or ester linkage. Structural classification of saponins is primarily based on their sapogenin skeletons, which can be divided into two main groups-Triterpenoid saponins and steroid saponins [1,2]. Triterpenoid saponins are broadly distributed in dicotyledons, including four major skeletons-Pentacyclic oleanane, ursane, lupane, and tetracyclic dammarane (Figure 1a); steroid saponins are mostly derived from monocotyledons, comprised of four major skeletons-Tetracyclic cholestane, hexacyclic spirostane, pentacyclic furostane, and lactone-bearing cardenolide (Figure 1b). Sugar-bearing sapogenins are categorized by numbers of sugar residue in monodesmosidic (one sugar residue), bidesmosidic (two sugar residues), and polydesmosidic saponins (three or more sugar residues) [3].

In nature, saponins are found in plants and marine animals, where they are implicated in host defense against pathogens and herbivores [4]. Since saponins are presented in many medicinal plants and Chinese herbal medicines, exhibiting a plethora of biological activities, including antifungal, antimicrobial, antiviral, anti-inflammatory, anticancer, antioxidant, and immunomodulatory effects, they can serve as a good starting point for the development of natural product-derived drugs [5]. However, the mechanism and SAR of saponins is poorly understood, and the isolation from plants to get appropriate amounts is sometimes troublesome and laborious due to microheterogeneity and scarcity of the molecules. As a result, applying an organic synthesis method to generate artificial saponins is a promising way to efficiently expand the structure library and search for highly active compounds $[6,7]$. 
(a)

Triterpenoid

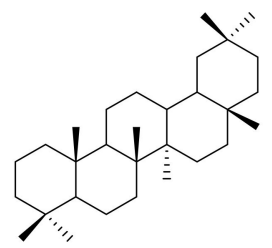

Oleanane

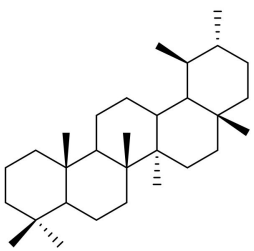

Ursane

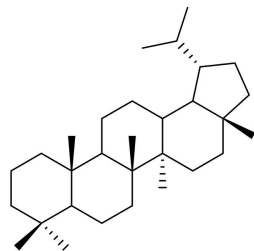

Lupane

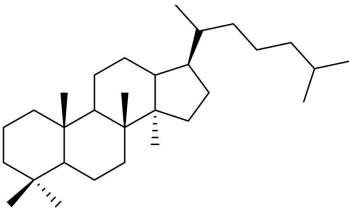

Dammarane

(b)

\section{Steroid}

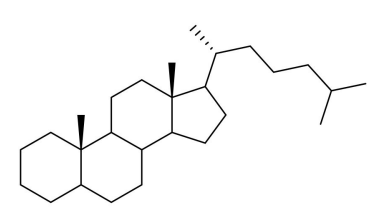

Cholestane

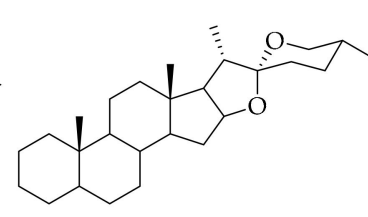

Spirostane

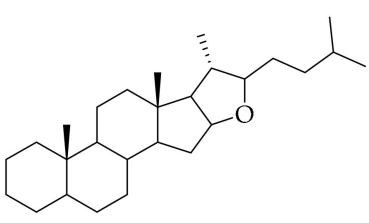

Furostane

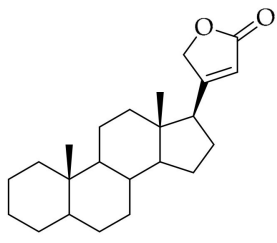

Cardenolide

Figure 1. Representative sapogenin structure of (a) triterpenoid saponins and (b) steroid saponins.

The number of research articles related to saponin have risen sharply in the past decade, indicating that the field is receiving more and more attention, requiring the need to broaden structure diversity efficiently. The synthetic methods of saponins have been well reviewed, providing complete information on the organic synthesis to perform SAR optimization [6,7]. Based on the research experiences on carbohydrate [8,9] and medicinal [10-22] chemistry in our lab, we summarize the biological effects and preliminary SAR results of synthetic saponins over the last five years to serve as a bridge between chemistry and biology, providing an insight for further structure optimization and mechanism studies, finally facilitating the development of saponin-based bioactive compounds.

\section{Triterpenoid Saponin}

\subsection{Oleanane}

Oleanane-type saponins are the most studied synthetic saponins, due to their promising pharmacological effects and high natural abundance. Common oleanane-type skeletons modified with a chemical approach are oleanolic acid, hederagenin, and quillaic acid. They have been isolated from enormous plant species as either a free triterpenoid or a saponin and are particularly rich in the Oleaceae family [23]. Oleanane-type saponins are reported to exhibit multiple biological activities, especially antitumor, antiviral and immunomodulatory effects [24-26]. However, toxicity triggered by hemolytic and membrane lysis effect is the major challenge in drug development [27], and the understanding of structure-toxicity relationships is at an early stage [28].

\subsubsection{Oleanolic Acid}

Synthetic oleanolic saponins (Figure 2) have been evaluated on their antitumor [14,18,21,29-37], anti-Alzheimer [38], antiviral [39,40], antiglucosidase [41], immunomodulating [42], and detoxification [43] activities (Table 1). Yang and co-workers reported a series of structures derivatized from potent antitumor Pulsatilla saponins, hederacolchiside A and D, elucidating the selectivity between the antitumor activity and hemolytic toxicity of compounds. The modification at 28- $\mathrm{COOH}$ of hederacolchiside was found to reduce toxicity with conservative antitumor efficacy, compared to hederacolchiside $A_{1}\left(H_{1}\right)$. Compound 1 with glycine-derived amide [36] and 2 with methyl ester [33] showed a promising cytotoxic $\mathrm{IC}_{50}$ as $0.9-3.2 \mu \mathrm{M}$ and $1.1-4.6 \mu \mathrm{M}$, respectively, against several human cancer cell lines and did not trigger acute toxicity in mice. With further modifications, ester-derived nitric oxide-donating 
compound 3 shows a cytotoxic $\mathrm{IC}_{50}$ in vitro between 1.6 and $6.5 \mu \mathrm{M}$ and better in vivo antitumor efficacy than $\mathrm{HA}_{1}$ without acute toxicity [32]. The attempt to enhance antitumor activity by altering the sugar contents of the trisaccharide moiety on $\mathrm{HA}_{1}$ was unable to generate a better compound, indicating the construction of a hydrophilic sugar chain was not directly related to antitumor activity [34,44]. Cheng and co-workers constructed a series of $\mathrm{HA}_{1}$ derivative via $\mathrm{Cu}(\mathrm{I})$-catalyzed azide-alkyne cycloaddition, and compounds modified with more lipophilic moiety (4) were found to exhibit higher antitumor activity than $\mathrm{HA}_{1}$ in a $0.5-2.7 \mu \mathrm{M}$ range [35]. Further mechanistic studies revealed that the compound 4 could activate HepG2 cell apoptosis through mitochondria-mediated intrinsic apoptosis pathways.

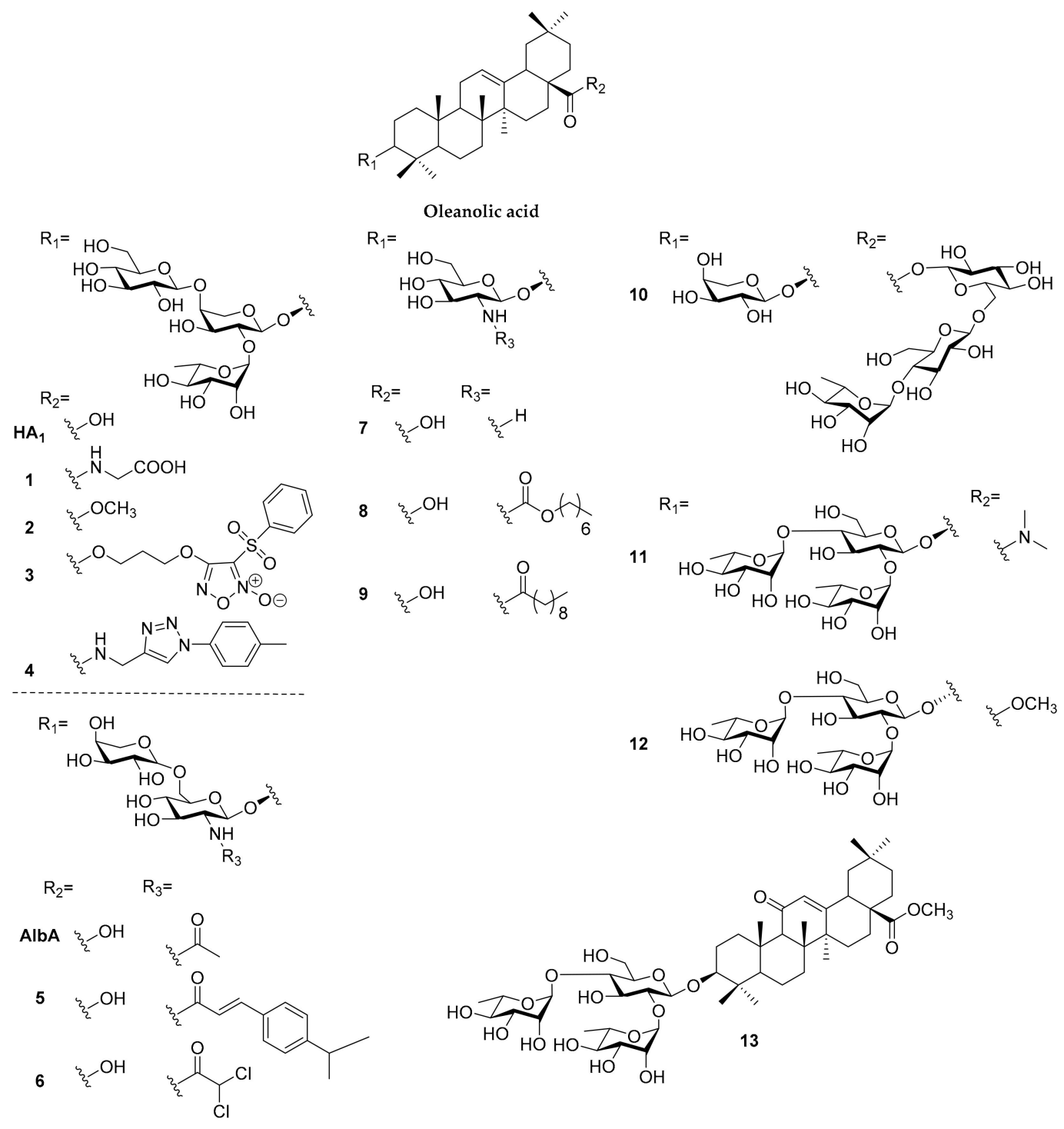

Figure 2. Synthetic saponins derived from oleanolic acid. 
Table 1. Biological effects of the synthetic saponins.

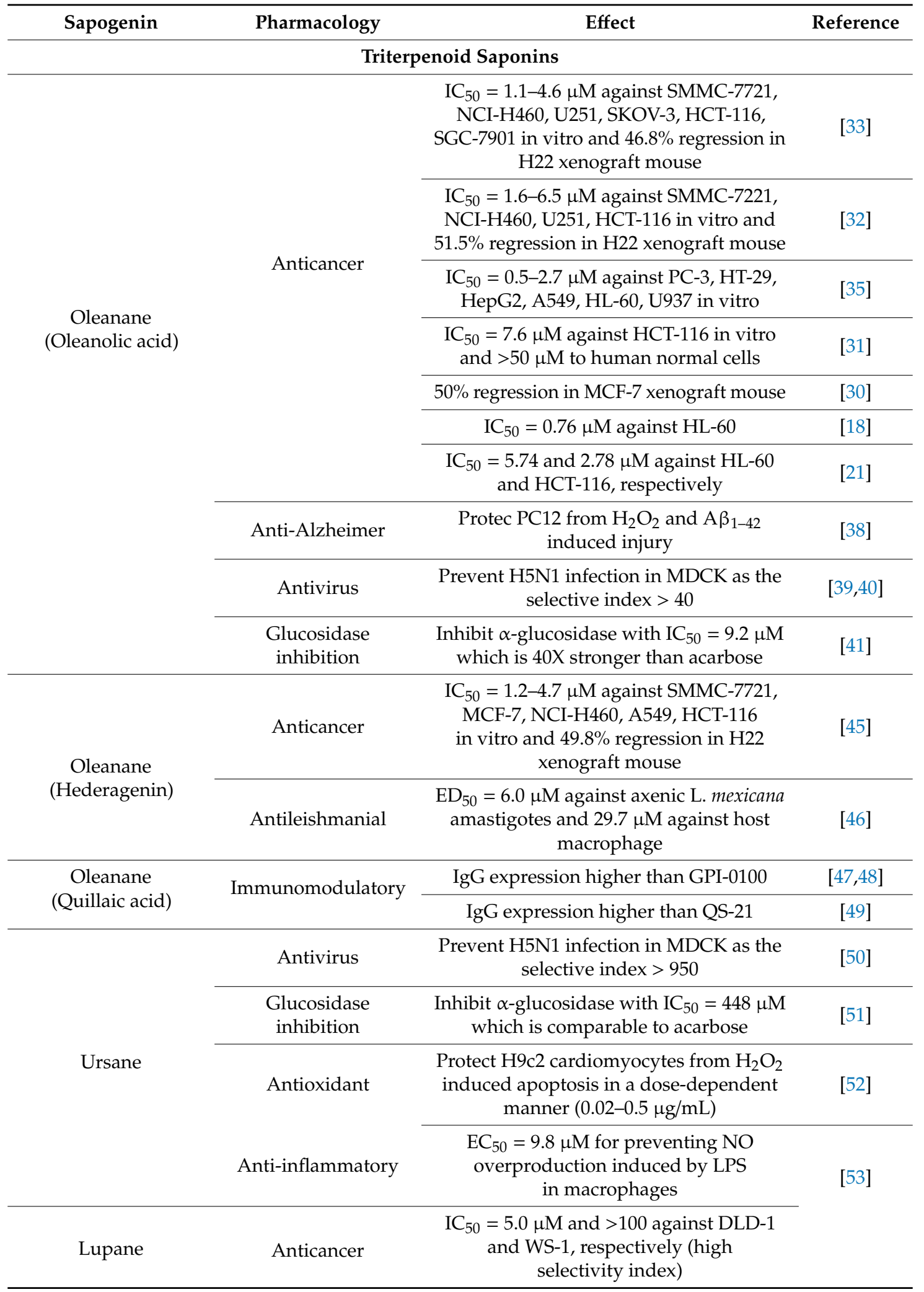


Table 1. Cont.

\begin{tabular}{|c|c|c|c|}
\hline Sapogenin & Pharmacology & Effect & Reference \\
\hline & & $\begin{array}{l}\mathrm{IC}_{50}=1.7 \text { and } 4.2 \mu \mathrm{M} \text { against MCF- } 7 \text { and } \\
\mathrm{HDFa} \text {, respectively (low selectivity index) }\end{array}$ & {$[54]$} \\
\hline & & $\begin{array}{c}\mathrm{IC}_{50}=0.9-2.6 \mu \mathrm{M} \text { against } \mathrm{CEM}, \mathrm{MCF}-7, \\
\text { HeLa, G-361 and } 1.3 \mu \mathrm{M} \text { against BJ } \\
\text { normal cells }\end{array}$ & {$[55]$} \\
\hline & Antibacterial & $\begin{array}{l}\text { MIC }=7.8-15.5 \mu \mathrm{g} / \mathrm{mL} \text { against } \\
\text { Staphylococcus aureus }\end{array}$ & {$[56,57]$} \\
\hline \multirow{4}{*}{ Dammarane } & Anticancer & $\mathrm{IC}_{50}=4.6 \mu \mathrm{M}$ against HeLa cells & [58] \\
\hline & Antioxidant & $\begin{array}{l}\text { Inhibit the AAPH-induced hemolysis in } \\
\text { rabbit erythrocytes }\end{array}$ & {$[59]$} \\
\hline & Antiasthma & $\begin{array}{c}\text { Effective in reducing IgE plasma level and } \\
\text { airway resistance in OVA-induced } \\
\text { asthmatic mouse model }\end{array}$ & {$[60]$} \\
\hline & Skin protection & $\begin{array}{l}\text { Conjugation of ginsenoside } \mathrm{Rh} 2 \text { with } \\
\mathrm{ZnONcs} \text { can increase SPF rating and } \\
\text { reduce toxicity in HaCaT cells }\end{array}$ & {$[61]$} \\
\hline \multicolumn{4}{|c|}{ Steroid Saponins } \\
\hline \multirow{3}{*}{ Cholestane } & \multirow{3}{*}{ Anticancer } & $\begin{array}{l}\mathrm{IC}_{50}=0.0012-13.0 \mu \mathrm{M} \text { against HCT-116, } \\
\text { NCI-H1975, Capan2, SW1990, SK-N-SH, } \\
\text { BGC823, HepG2. }\end{array}$ & {$[62]$} \\
\hline & & $\begin{array}{c}\mathrm{IC}_{50}=0.0054 \text { and } 0.16 \mu \mathrm{M} \text { against Jurkat } \\
\text { cancer cells and CRL1999 normal } \\
\text { cells, respectively }\end{array}$ & {$[63]$} \\
\hline & & $\begin{array}{c}\text { Identify the apoptosis induced by OSW-1 } \\
\text { might result from Golgi response through } \\
\text { CREB3-ARF4 pathway and interaction } \\
\text { between OSW-1 and cholesterol }\end{array}$ & {$[64,65]$} \\
\hline \multirow{3}{*}{ Spirostane } & \multirow[t]{2}{*}{ Anticancer } & $\begin{array}{c}\mathrm{IC}_{50}=1-2 \mu \mathrm{M} \text { against leukemia cell } \\
\mathrm{CCRF} \text { and induced a profound increase in } \\
\text { protein expression of } \\
\text { CCAAT/enhancer-binding protein } \alpha \\
(\mathrm{C} / \mathrm{EBP} \alpha)\end{array}$ & {$[13,66]$} \\
\hline & & $\begin{array}{c}\mathrm{IC}_{50}=2.7 \text { and } 4.6 \mu \mathrm{M} \text { against HepG2 and } \\
\text { MCF-7, respectiviely }\end{array}$ & [67] \\
\hline & $\begin{array}{l}\text { Antimicrobial and } \\
\text { Antifungal }\end{array}$ & $\begin{array}{c}\mathrm{MIC}=2-8 \mu \mathrm{g} / \mathrm{mL} \text { against Candida, } \\
\text { Staphylococcus, Enterococcus, Bacillus } \\
\text { species }\end{array}$ & {$[68]$} \\
\hline Furostane & $\begin{array}{l}\text { Glucosidase } \\
\text { inhibition }\end{array}$ & $\begin{array}{l}\text { Inhibit } \alpha \text {-glucosidase with } \mathrm{IC}_{50}=96 \mu \mathrm{M} \\
\text { which is } 12 X \text { stronger than acarbose }\end{array}$ & [69] \\
\hline \multirow{3}{*}{ Cardenolide } & \multirow{3}{*}{ Anticancer } & $\begin{array}{l}\text { Inhibit } 70 \% \text { of NIH-H460 cancer cells at } \\
\qquad 50 \mathrm{nM}\end{array}$ & [70] \\
\hline & & $\mathrm{IC}_{50}=0.108-3.27 \mu \mathrm{M}$ against MCF-7 & [71] \\
\hline & & $\begin{array}{l}\text { Inhibit cancer growth in } 0.01-0.1 \mu \mathrm{M} \\
\text { range and no toxicity at } 3 \mu \mathrm{M}\end{array}$ & [72] \\
\hline
\end{tabular}

Cheng and co-workers synthesized a series of albiziabioside A (AlbA) derivatives, of which the disaccharide analogues were less cytotoxic against cancer cells than parent compounds [37]. Therefore, the direction of structure optimization was changed to the modification of secondary amine residue on glucosamine, and the amide derivatives were found to be inactive against most of 
cancer cell lines except HCT116 colorectal cancer cells. Compound 5 exhibited cytotoxic selectivity between normal cells $(>50 \mu \mathrm{M})$ and HCT116 $(7.6 \mu \mathrm{M})$, and the antiproliferative activity might be related to mitochondria-dependent apoptosis [31]. To further improve antitumor efficacy, a secondary amine moiety of AlbA was conjugated with dichloroacetate (6), a pyruvate dehydrogenase kinase inhibitor, to disrupt glycolysis pathway in cells, leading to increased intracellular reactive oxygen species (ROS) and decreased accumulation of lactic acid in the tumor microenvironment. The cancer cell death was induced by caspase-dependent pathway activation, GPX4 pathway suppression, and lipid peroxidation accumulation, which can be summarized into apoptosis-ferroptosis-M2-TAM polarization [30]. Sun and co-workers constructed the synthesis method of four naturally occurring oleanolic saponins, revealing that monodesmosidic saponin exhibited higher antitumor cytotoxicity than bidesmosidic saponin [29].

Since 2014, our group had studied the $N$-acetyl glucosamine-bearing oleanolic saponins, which were found in plants and showed promising antitumor cytotoxicity against several cancer cell lines [44]. To investigate the influence of activity on the sugar chain, we constructed a series of oleanolic saponins with $(1 \rightarrow 3)$-linked, $(1 \rightarrow 4)$-linked, and $(1 \rightarrow 6)$-linked $N$-acetylglucosamine oligosaccharide residues; it was found that derivatives bearing modifications to the $3^{\prime}$-glycosyl moiety and/or those

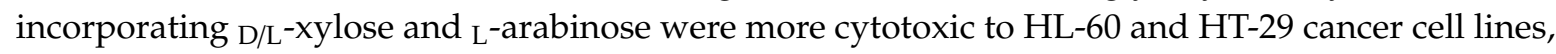
but still less cytotoxic than the oleanolic saponin bearing a single $N$-acetylglucosamine (7) [14]. Based on this finding, we modified the secondary amine moiety and generated $N$-acyl, $N$-alkoxycarbonyl and $N$-alkylcarbamoyl derivatives with different lengths of carbon chains. Their cytotoxicity against HL-60 cell were related to the length of the carbon chain in a bell-shaped manner, with seven to nine carbons showed promising efficacy and the carbamate bridge being better than amide and urea $(8$ and $\mathbf{9}, 0.76$ and $1.40 \mu \mathrm{M}$ respectively). Cell imaging revealed the cytosolic distribution of the compounds and the mitochondrial membrane potential loss identified with JC-1 dye made us believe that the cytotoxicity of saponins originated from the mitochondria-dependent pathway [18]. Interestingly, with flow cytometry analysis and detailed confocal imaging, the bell-shaped activity phenomenon was due to the cell penetrating effect of our compounds. Compounds with long carbon chains would stick on cell membranes, leading to lower cytotoxicity against cancer cells. To further elucidate the mechanism of our compound in causing HL-60 cell death, we applied the Annexin V/DRAQ5 assay to identify the apoptosis-triggering effect, and the cell cycle analysis found that HL-60 cancer cells were arrested in the sub-G1 phase in a dose-dependent manner. Combining the results of western blotting and stable isotope labeling by/with amino acids in cell culture (SILAC) proteomics, glucosamine-bearing oleanolic saponin was found to trigger both intrinsic and extrinsic apoptosis and inhibit the PI3K/Akt/mTOR pathway in HL-60 cancer cells [21].

Evaluation of the neuroprotective effect of hederacolchiside E derivatives bearing various sugar chains was performed by Cheng and co-workers; compound $\mathbf{1 0}$ was found to prevent cell death by reducing the release of lactate dehydrogenase, level of intracellular ROS, and malondialdehyde resulting from $A \beta_{1-42}$ treatment in PC12 cells [38]. Song and co-workers generated a series of $3-O-\beta$-chacotriosyl oleanolic saponins serving as entry inhibitors of $\mathrm{H} 5 \mathrm{~N} 1$, revealing that a disubstituted amide modification at 28-COOH (11), alteration of C-3 configuration from $\beta$ to $\alpha(\mathbf{1 2})$, and introduction of an oxo group to $\mathrm{C}-11$ of oleanolic acid (13) can enhance the selectivity index between antiviral and toxicity [39,40]. Kobayashi and co-workers explored the mucosal adjuvant activity of oleanolic saponins with a cinnamoyl-modified glycosyl moiety at 28-COOH for generating nasal anti-influenza virus antibodies, showing mild IgG and IgE enhancements [42]. They also revealed the ability of oleanolic acid 3-glucoside to suppress the methylmercury accumulation in vitro and in vivo, serving as a toxicity alleviation agent for methylmercury [43]. Liu and co-workers synthesized two derivatives based on a Gypsophila oldhamiana saponin, where they demonstrated that the $\mathrm{C}-4 \mathrm{OH}$ have better $\alpha$-glucosidase inhibition activity than $\mathrm{C}-4 \mathrm{CHO}$ or $\mathrm{C}-4 \mathrm{CH}_{2} \mathrm{OH}[41]$. 


\subsubsection{Hederagenin}

Synthetic triterpenoid saponins based on hederagenin (Figure 3) have been reported to exhibit cytotoxicity against cancer cells $[45,73,74]$ and antileishmanial activities [46] (Table 1). Yang and co-workers synthesized a series of hederagenin-type saponin derivatives from pulsatilla saponins A and D (PSA, PSD), bearing modifications to the sapogenin moiety. However, none of the saponin derivatives tested showed superior cytotoxicity in cancer cells compared to parent saponins and hederagenin derivatives [73,74]. To further expand the SAR of PSD, several 28-COOH esters and amide derivatives were synthesized, and compounds 14 and 15 showed better cytotoxicity in five human cancer cell lines ( $\mathrm{IC}_{50}=1.2-4.7 \mu \mathrm{M}$ and $1.7-4.5 \mu \mathrm{M}$, respectively) and lower acute toxicity to mice than PSD. Moreover, compound 15 was found to kill HCT-116 through apoptosis, causing G1 cell cycle arrest, and showed similar antitumor efficacy in vivo compared to PSD [45]. A large library of semi-synthetic hederagenins and their saponins were evaluated on their antileishmanial properties, but could not acquire ideal selectivity index in eliminating axenic L. Mexicana amastigotes and toxicity to host a macrophage (RAW 267.4) [46].

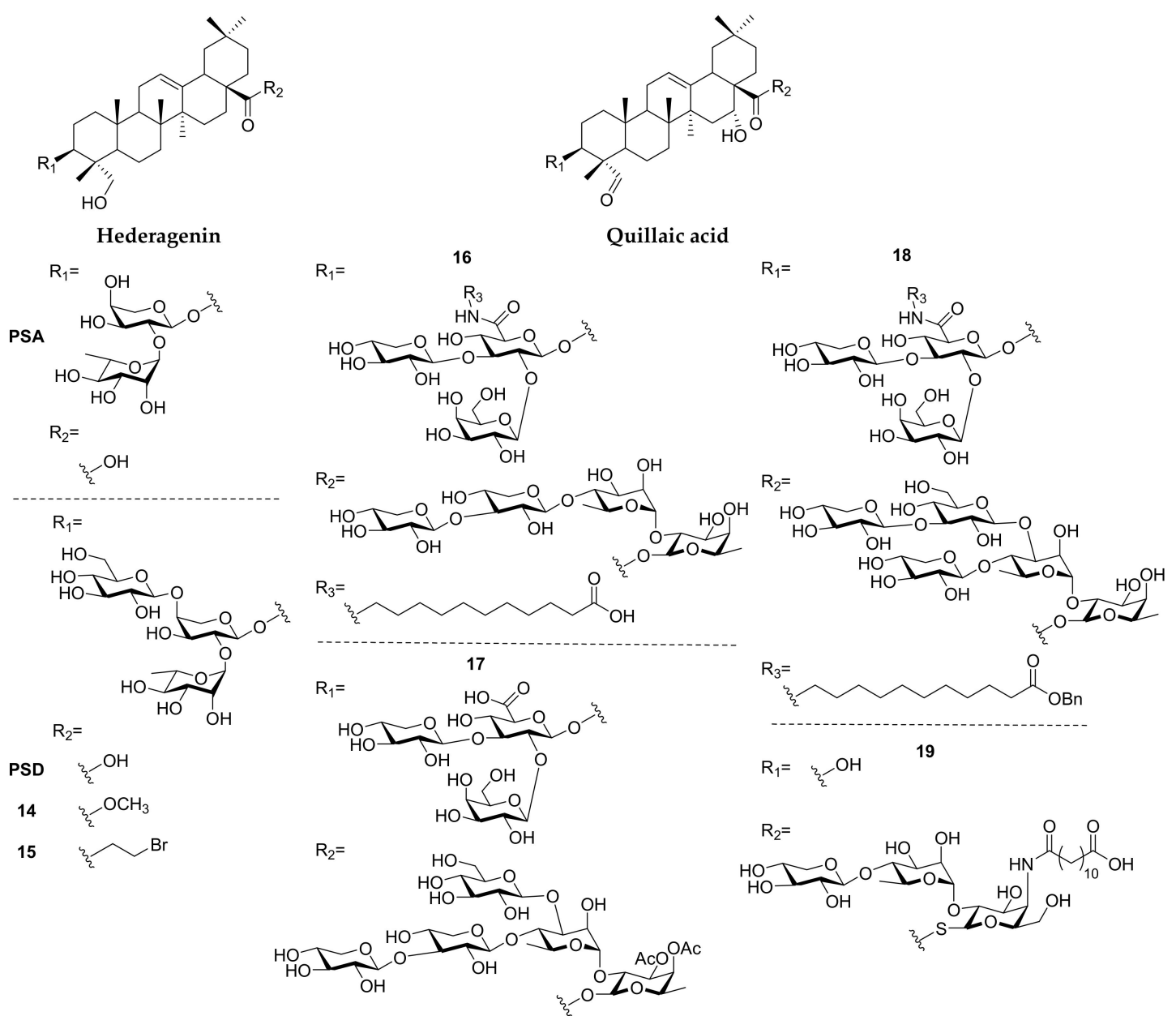

Figure 3. Synthetic saponins derived from hederagenin and quillaic acid.

\subsubsection{Quillaic Acid}

Synthetic quillaic saponins (Figure 3), based on Quillaja saponaria saponins, are mostly studied for their immunomodulatory activities (Table 1) [75]. The first synthesis of Quillaja saponins fraction-21 (QS-21) was established by Gin and co-workers [76] and they accomplished extensive SAR studies, which have been completely summarized in a previous review [77]. Recently, Wang and co-workers dedicated themselves to the expansion of SAR knowledge in various isolating fractions of Quillaja saponins. 
In QS-21-based saponins, the derivatization on glucuronic acid was found to improve adjuvanticity with terminal carboxylic acid (16) or monosaccharide modification $[47,78]$. The derivatization of QS-17/18-based saponins with amide coupling could only achieve similar adjuvanticity to GPI-0100, a QS-21 derivative with a lower toxicity [79]. To investigate the relationship between the hexasaccharide on 28-COOH of QS-7 and immunomodulatory efficacy, a series of compounds bearing different sugar chains were synthesized, and compound 17, with acetyl-modified pentasaccharide, was found to exhibit the most potent adjuvanticity, even similar to QS-21 $[49,80]$. Since the amounts of Quillaja saponin were extremely low in the bark of Quillaja saponaria, Momordica saponins were found to be a surrogate source of Quillaja saponins, and the amide-modified compound $\mathbf{1 8}$ can trigger better adjuvanticity than GPI-0100 [48,81]. The group of Fernandez-Tejada synthesized several 3-O-truncated QS-21 derivatives, revealing that the replacement of ester linkage by thioester at $28-\mathrm{COOH}$ preserved the activity (19), and echinocystic acid was found to exhibit similar adjuvanticity to their quillaic congeners [82].

\subsection{Ursane}

Ursolic acid is a pentacyclic triterpenoid mostly isolated from berries, especially cranberries (Vaccinium macrocarpon), and other Vaccinium species [83]. Multiple biological activities are found in the synthetic ursolic acid derivatives (Figure 4), such as antiviral, cardioprotective, anticancer and anti-inflammatory effects (Table 1 ) $[84,85]$. Song and co-workers synthesized a series of 3 -O- $\beta$-chacotriosyl ursolic acid serving as entry inhibitors of H5N1, and the SAR evaluation demonstrated a similar observation to their study of the derivatives of oleanolic acid. Amide modification at $28-\mathrm{COOH}(20)$ and altering C-3 configuration from $\beta$ to $\alpha$ (21) improved the selective index greatly [50,86-88]. Hong and co-workers synthesized several bis-disaccharide and mono-disaccaride-bearing dihydroxytriterpenes, and corosolic acid bis-lactoside was found to possess anti- $\alpha$-glucosidase activity close to acarbose [51].

Sun and co-workers generated the analogues of calenduloside E (CE, Figure 4), isolated from Aralia elata, and evaluated their protective effects in preventing $\mathrm{H} 9 \mathrm{c} 2$-cardiomyocytes apoptosis induced by oxidative stress. Compound 22 (Figure 4), $28-\mathrm{N}$-amido-3-O- $\beta$-D-galactopyranosyl ursolic acid, exhibited the best cytoprotective effect, and was found to inhibit ROS generation, maintain mitochondrial membrane potential and reduce caspase-dependent apoptosis cascade [52]. To elucidate the cytoprotective mechanism of $\mathrm{CE}$, Sun's group introduced an alkyne to $28-\mathrm{COOH}$ of $\mathrm{CE}$ with amide linkage (23), and the binding with Hsp90AB1 was identified through the biotin-streptavidin system in human umbilical vein endothelial cells (HUVEC). Further biological assays demonstrated that CE can reverse the reduction in Hsp90AB1 after ox-LDL treatment and the binding of CE to Hsp90AB1 was increased in a dose-dependent manner [89]. On the other hand, the alkyne protein probe of the CE analogue (24) revealed a similar result when binding with Hsp90 [90].

\subsection{Lupane}

The most well-known synthetic lupane-type saponins are those derived from betulinic acid and lupeol, which are usually isolated from white birch bark [91]. Lupane-type saponins are reported to exhibit anti-inflammatory, antiviral and antitumor activities (Figure 4) [92-94]. However, the drug development of lupane-type compounds is limited by their low water solubility and poor pharmacokinetic profiles [95]. Efforts to improve these properties prior to 2011 have been completely reviewed [96]; therefore, our discussion was focused on the development of lupane-type saponins after 2011 (Table 1).

Legault and co-workers have demonstrated that a bidesmosidic betulinic saponin $28-O-\alpha$-L-rhamnopyranosyl betulin $3 \beta-\mathrm{O}-\alpha$-L-rhamnopyranoside (Bi-L-RhamBet) induced lung cancer cell death through the mitochondrial electron transfer chain which induced ROS production and decreased membrane potential, leading to apoptosis and DNA fragmentation [97]. Based on the findings, Pichette and co-workers synthesized $\alpha_{-}-$-rhamnose-containing betulinic and ursolic saponins, which exhibited cytotoxicity against human colorectal adenocarcinoma cells DLD-1 $\left(\mathrm{IC}_{50}=5 \mu \mathrm{M}\right)$ 
and low toxicity in human skin fibroblasts WS-1 $\left(\mathrm{IC}_{50}>100 \mu \mathrm{M}\right)$ in dirhamnoside-bearing betulinic derivatives (25) and anti-inflammatory activity was revealed in ursolic derivatives (26) [53]. Liberek and co-workers synthesized glucosamine- and galactosamine-containing betulinic saponins, revealing that galactosamine derivative (27) exhibited high cytotoxicity in both MCF-7 breast cancer cells and HDFa normal cells (1.7 and $4.2 \mu \mathrm{M}$, respectively), and had no inhibition activity toward bacteria and fungi [54]. Several peracetylated glucosamine-modified betulin and allobetulins have been synthesized by Kataev and co-workers, found to exhibit antibacterial efficacy (minimum inhibitory concentration, MIC = 7.8-15.5 $\mu \mathrm{g} / \mathrm{mL}$ ) against Staphylococcus aureus [56,57].

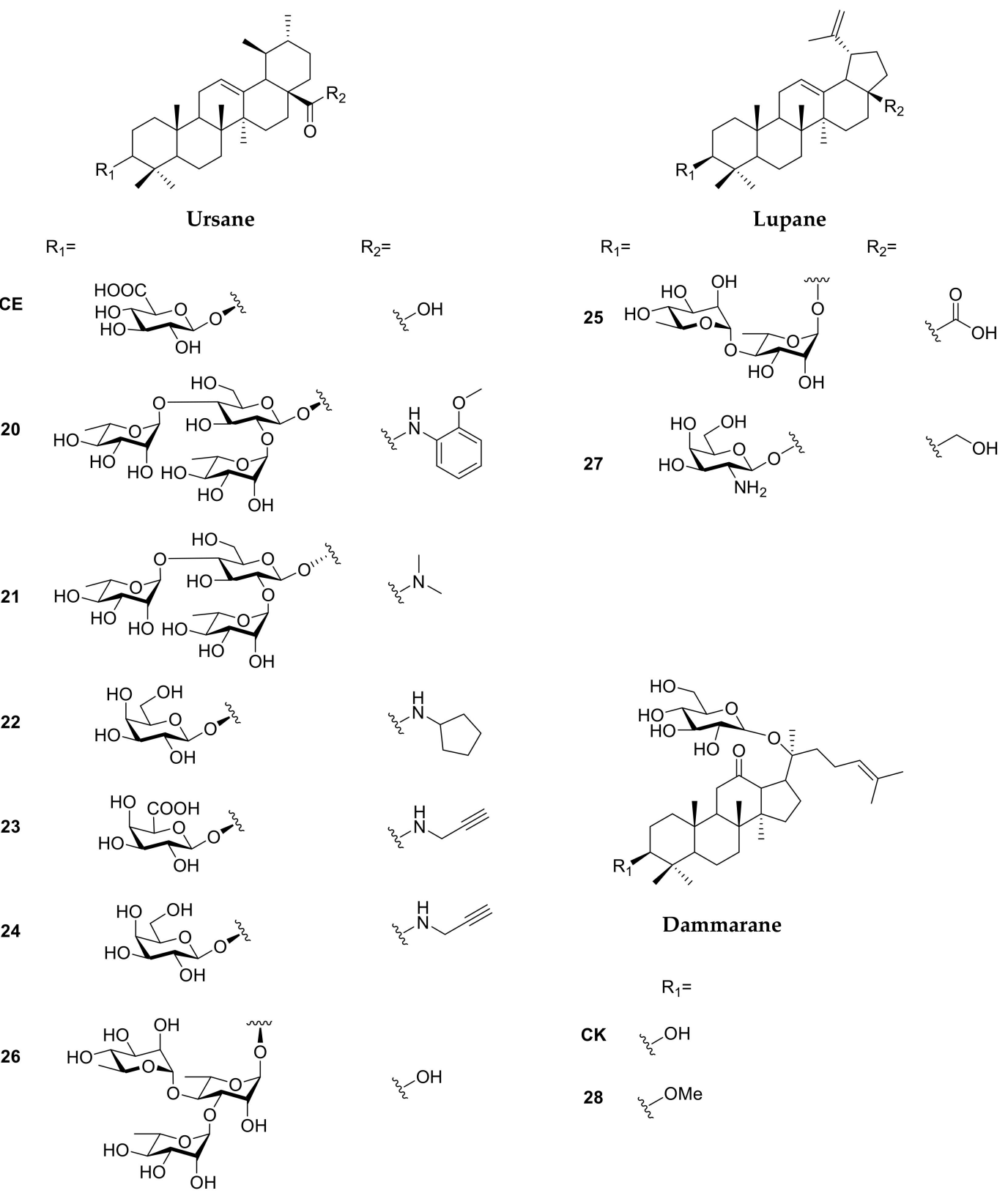

Figure 4. Synthetic saponins derived from ursane-, lupane-, and dammarane-type sapogenins.

Pakulski and Strnad developed a series of lupane- (modified at 3-OH position) and homolupane-based (modified at 28-COOH position) saponins, including 3-O-glycoside, 28-COO-glycoside, 28-COO-thioglycoside, 28-COO-selenoglycoside and bidesmosidic saponins. 
However, all the compounds tested were either poorly cytotoxic to cancer cells, or poorly selective for cancer cells over normal cells [55,98-101].

\subsection{Dammarane}

Representative dammarane-type saponins are ginsenoside (isolated from Panax ginseng), gypenoside (from Gymnostemma pentaphyllum), bacoside (from Bacopa monnieri), and gymnemic acid (from Gymnema sylvestre), all of which have been extensively studied for their biological activities [5]. Although the naturally occurring dammarane-type saponins have been studied for a long time [102], SAR studies revealed that chemically generated synthetic saponins were mainly on ginsenoside derivatives and were still far from satisfactory $[103,104]$. Based on the recent progress in organic synthesis (Figure 4) [105,106], several studies showed cytotoxicity against cancer cells $[58,107,108]$, as well as antioxidative [59], antiasthma [60] and skin-protective effects [61] of ginsenoside derivatives (Table 1).

Modifications to the C-20 side chain of the ginsenosides demonstrated that the hydroxylation site and configuration at C-20 and C-24 profoundly influenced cytotoxicity, in which ginsenoside derivatives bearing a monosaccharide at C-3 and a disaccharide at C-6 were more cytotoxic than those without modification $[58,107,108]$. Another study found that ginsenosides incorporating a Z-configuration at C-20 exhibited higher antioxidative activity than those not, and those bearing a disaccharide moiety at the C-3 position exerted a stronger hemolytic effect [59]. In other work, $\mathrm{Li}$ and co-workers evaluated the in vivo anti-IgE activity of a series of ginsenoside compound K (CK and 28, Figure 4) analogues in an ovalbumin (OVA)-induced asthmatic mouse model; compounds modified at C20 and ketoxime exhibited a comparable antiasthmatic effect to CK [60]. Additionally, the conjugation of ginsenoside Rh2 onto polymer-functionalized zinc oxide nanocomposites generated water-dispersible materials capable of absorbing, scattering, and reflecting UV radiation, exemplifying their potential as nanomaterial sun-blockers [61].

\section{Steroid Saponin}

\subsection{Cholestane}

Studies of synthetic cholestane-type saponins have focused on SAR studies of OSW-1 and SBF-1 analogues, with monodesmosidic saponins isolated from Ornithogalum saundersiae in 1992 (Figure 5) [109], due to high antitumor efficacy and low toxicity (Table 1), and the SAR studies related to these structures were completely summarized in a review paper published in 2013 [110]. Recently, Lei reported several novel OSW-1 analogues bearing disaccharides consisting of cinnamoylor methoxybenzoyl-modified xylose and arabinose with either a $(1 \rightarrow 3)$ or $(1 \rightarrow 4)$ linkage at the 16-OH position. The conformation of the carbohydrate moiety was found to strongly influence antitumor activity, with the $(1 \rightarrow 3)$-linked analogue exhibiting potent antiproliferative activity and adopting a chair conformation (29), whereas the $(1 \rightarrow 4)$-linked analogue adopted a boat conformation and was inactive [62]. 


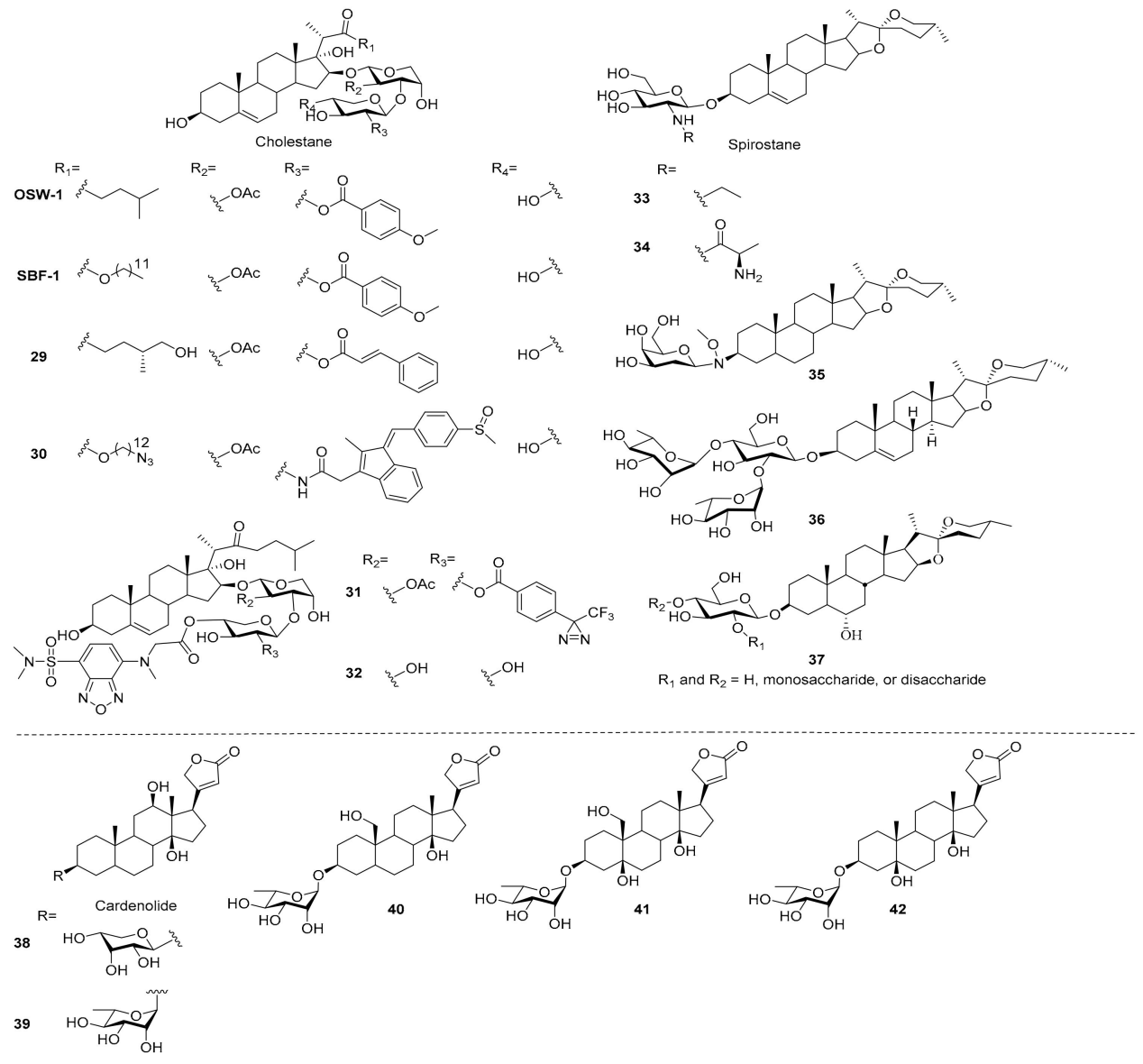

Figure 5. Synthetic saponins derived from steroid-type sapogenins.

In 2019, Yu and co-workers developed a series of SBF-1 C22-ester analogues bearing 2-acylamine xylose residues which were up to 40-fold more cytotoxic to Jurkat and MDA-MB-231 cancer cell lines compared to SBF-1 and taxol, but they had no selectivity to normal cells. Although the cytotoxicity was lower, compounds with complex acyl group on 2-N position of xylose (30) were found to increase the selectivity index. Besides, an analogue with photoaffinity and clickable moiety was also synthesized and can be applied to target identification in the future [63].

Sakurai sought to understand the anticancer mechanisms of OSW-1 by conjugating a fluorescent moiety to the $3^{\prime \prime}$-position and studied the distribution of compounds in the cell by a fluorescence microscope. The probe was found to concentrate in the ER and Golgi within $10 \mathrm{~min}$ in a temperature-dependent manner [111]. OSW-1 was also derivatized selectively at the 4 "'-position with a good to excellent yield using an organotin reagent, to give analogues bearing a fluorescent tag, biotin tag or alkyne moiety for further biological studies [112]. On the other hand, they also performed the $4^{\prime \prime}$ position-selective synthesis of a clickable photoaffinity probe, and confirmed its probing activity with a proof-of-concept experiment using bovine serum albumin [113]. Sequential derivatization was applied to the synthesis of dual functional OSW-1 derivatives 31 which bore fluorescence and photoaffinity moieties and had a comparable cytotoxicity to OSW-1 [114]. The deacetylated OSW-1 was known to exhibit a significantly lower cytotoxicity than the parent compound; however, Sakurai's group synthesized 32 which displayed the same cell distribution pattern with fluorescence labeling, indicating that acetyl modification was not necessary for cell penetration [115]. A further mechanism study revealed that the ability of OSW-1 to trigger an apoptotic Golgi response was through CREB3-ARF4 pathway, and it might be an important reason in the selectivity between normal cells and cancer cells [64]. By accessing membrane-disrupting activity, the interaction between OSW-1 and cholesterol was found to be important in membrane permeabilization and hemolytic activity $[65,116]$, but the membrane 
activity of OSW-1 proceeded without destroying membrane integrity comparing to other saponins, which might be another reason for the cytotoxic selectivity of OSW-1.

\subsection{Spirostane}

In the field of chemical synthesis, spirostane-type saponins are majorly derived from diosgenyl glycosides (Figure 5), widely distributed in legumes, fenugreek and yams, and are found to exhibit promising biological effects, such as metabolic regulation, anticancer, neuroprotective and antithrombotic activities (Table 1) [13,117-120]. In 2013, we reported the synthesis of a series of chlorogenin-type saponins with an orthogonal-protecting group strategy to modify the chacotriose moiety on the 3-OH of chlorogenin. Ten different glycoside donors, including di-, tri-, and tetrasaccharides, are synthesized and conjugated to 3-O- $\beta$-D-glucopyranosyl chlorogenin in 34-95\% yields. Unfortunately, all of the derivatives show weak inhibition activity against CCRF, HL60, and PC-3 cancer cells and are inactive toward the inhibition of influenza virus entry [13]. Since attempts to modify dioscin failed, it was suggested that dioscin might have an unique property in dioscin-induced apoptosis in leukemic cells which was identified through the death receptor-mediated extrinsic and intrinsic apoptosis pathways. More importantly, dioscin induced a profound increase in protein expression of CCAAT/enhancer-binding protein $\alpha(\mathrm{C} / \mathrm{EBP} \alpha)$, which was a critical factor for myeloid differentiation [66].

Recent studies focused on the antimicrobial and antitumor activities of spirostane-type saponins. For example, Liberek evaluated the antimicrobial and antifungal activities of diosgenyl 2-amino-2-deoxy- $\beta$-D-glucopyranoside, and its $N$-alkyl and $N, N$-dialkyl derivatives. The $N$-ethyl (33) and $N$-propyl derivatives were found to exhibit stronger activity against Gram-positive bacteria and Aspergillus niger than underivatized diosgenyl saponin [121]. The importance of the carbohydrate moiety was also investigated by conjugating the galactosamine and then synthesizing a series of $\mathrm{N}$-acyl, 2-ureido and $\mathrm{N}$-alkyl derivatives. Interestingly, the alteration of glucosamine into galactosamine greatly diminished the antibacterial and antifungal activity, but activities were recovered in the derivatives with $\mathrm{N}$-ethyl, $\mathrm{N}$-acetyl and 2-chloroethylureido modifications, which presented a similar trend to glucosamine derivatives [122]. Since the glucosamine-bearing diosgenyl saponins exhibited better activities, Liberek and co-workers replaced the $\mathrm{N}$-alkyl into $\mathrm{N}$-aminoacyl and $\mathrm{N}$-hydroxyacyl moieties. $\mathrm{N}$-aminoacyl saponins (e.g., 34) exhibited ideal antifungal activity and growth inhibition effects in Gram-positive bacteria, and the compounds with better activity belonged to sarcosines or L-

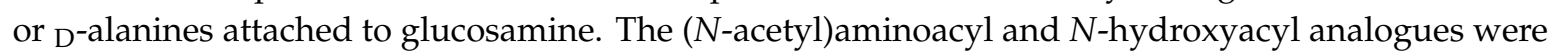
all inactive, indicating the free amino group in glucosamine residue was necessary for their antifungal and antibacterial effects. With the exposure of the saponins to human erythrocytes, the hemolytic activities were found to be independent of the antibacterial efficacy [68].

Tigogenin is a spirostane-type sapogenin isolated from Yucca gloriosa L. and found to exhibit very low antiproliferative activity. However, tigogenin derivatives bearing saccharide chains showed greatly enhanced antitumor activities in several cancer cell lines, including HL-60 cells [123]. Zhang and co-workers synthesized a series of tigogenin saponins bearing different sugar moieties using an oxyamine neoglycosylation method. Tigogenin bearing a 2-deoxy-galactose (35) exhibited IC $_{50}$ values of 2.7 and $4.6 \mu \mathrm{M}$ against HepG2 and MCF7 cancer cell lines, respectively. On the other hand, the 3R-tigogenin neoglycosides showed enhanced antitumor activity and the $3 \mathrm{~S}$ isomers were not active, suggesting that the configuration of glycosidic bonds was important for cytotoxicity against cancer cells [67].

\subsection{Furostane}

Furostane-type saponins are characterized by a hemiketal ring and carbohydrate moiety attached to the 3-OH and/or 26-OH of sapogenin. Easy conversion of furostane-saponins to spirostane-saponins and the microheterogeneity made the isolation of furostane-saponins from natural sources become problematic and difficult. Therefore, several chemical works have been established for the synthesis 
of furostane-type saponins using 26-hydroxy-16, 22-dioxo-cholestan as a building block, providing efficient tools to expand SAR knowledge for medicinal chemistry research [124-127].

$\mathrm{Li}$ and co-workers developed a concise and practical synthetic route for the synthesis of several furostane-type saponins from readily accessible $16 \beta$-acetoxy-22-oxo-cholestanic derivatives, which can be applied to SAR studies. The biological assay results demonstrated that funlioside B is a promising lead for $\alpha$-glucosidase inhibition (Table 1) [69].

\subsection{Cardenolide}

The earliest known cardiac glycosides (CGs) were isolated from Digitalis purpurea L. and have served as an oral treatment for heart failure and cardiac arrhythmia for centuries [128]. The cardioprotective activity of CG originates from their binding and inhibition of the cardiac myocyte membrane $\mathrm{Na}^{+} / \mathrm{K}^{+}$-ATPase, lowering the heart burden [129]. Interestingly, a recent drug-repurposing study found that cardiac glycosides triggered cancer cell apoptosis through various mechanisms [130], including exposure of calreticulin on the outer leaflet of cell membranes, active secretion of ATP via autophagy, and release of nonhistone chromatin-binding protein high mobility group box 1 (HMGB1) [131-133]. Several cardiac glycosides are now under investigation in Phase I and II clinical trials for solid tumor treatments and revealed a promising safety and efficacy [134].

The potent apoptotic effect (Table 1) of the cardiac glycosides spurred studies of their SARs (Figure 5). Tang and co-workers focused on the derivatization of the 3-O sugar moiety of digoxigenin to understand its influence on Nur77 protein induction, cytotoxicity, and apoptosis induction in NIH-H460 cancer cells. Applying oxyamine neoglycosylation to construct a series of 6-deoxy and 2,6-dideoxy-D-glucose derivatives of digoxin revealed that the induction of Nur77 protein expression was strong in some compounds but lacked sufficient cytotoxicity against cancer cells [135]. To further improve the cytotoxicity against NIH-H460 cancer cells, digoxigenin derivatives containing different carbohydrates at 3-OH were synthesized, and the $O$-linked saponins bearing $\mathrm{D}_{\mathrm{D}}$-ribose and $\mathrm{L}_{\mathrm{L}}$-rhamnose $(38,39)$ exhibited nanomolar range cytotoxicity which was better than digoxin. However, the inductions of the Nur77 protein only showed a low correlation to cytotoxic effects [70]. The biotinylated cardiac glycoside probes were derived from $\alpha$-antiarin and $\beta$-antiarin. They were found to increase Nur77 protein inductions. However, significant decrements of cytotoxicity against NIH-H460 cells were observed in all derivatives, indicating that the probe can only be applied to the study of Nur77 protein induction rather than cytotoxic efficacy in cancer cells of cardiac glycosides [136].

Total syntheses of sarmentogenin, trewianin, ouabagenin and other cardenolides have also been reported. Inoue and co-workers synthesized the sapogenin moiety of sarmentogenin and trewianin, as well as their glycosylated derivatives, revealing the important role of 3-O-glycosylation for cytotoxicity against MCF-7 cells [71]. Nagorny used a Cu (II)-catalyzed diastereoselective Michael/aldol cascade approach to synthesize cardiac glycosides incorporating carbon atoms in various states of oxidation. L- $\alpha$-rhamnosides of cannogenol (40), strophanthidol (41), and digitoxigenin (42) were found to exhibit broad cytotoxicity against cancer cells and were nontoxic at $3 \mu \mathrm{M}$ against normal cells and a developing fish embryo. The anticancer activity of these compounds involved DNA-damage upregulation and apoptosis induction [72]. Kinghorn and co-workers synthesized several (+)-digoxin derivatives. The SAR studies stated that C12 and C14 hydroxyl groups and an unsaturated lactone moiety were important for cytotoxicity; the 3-O-glycosyl moiety seemed to be less crucial [137]. Collectively, these reports have expanded the chemical tools available for the synthesis of cardiac glycosides and their derivatives.

\section{Discussion}

Saponins are a large and diverse class of natural products with intriguing and varied biological activities, but their development is limited by the microheterogeneity and difficulties associated with their isolation. Chemical synthesis has now been established as a powerful tool for the derivatization of saponins and the study of their SAR, leading to numerous exciting discoveries of molecules more 
potent and less toxic than those originally isolated [6]. The roles of carbohydrate in the bioactivity of saponin has been discussed extensively in cytotoxicity assays and can significantly influence the activity. In assays against cancer cells, the existence of carbohydrates showed both positive $[58,71,107,108]$ and negative $[37,55,98-101]$ effects. Changing the composition of sugar chains could enhance the cytotoxic effect $[14,29,67,70]$ but also showed no differences in some studies $[13,34]$. Nevertheless, the sugar chains containing monosaccharides were usually better than di- and polysaccharides [14,29]. These results showed the importance of a carbohydrate moiety in influencing biological activity.

The recently reported biological assays of synthetic saponin were focused on several disease models, including anticancer, anti-infection (antiviral, antibacterial, antileishmanial), immunomodulatory (immunostimulatory, antioxidant, anti-inflammation), antiglucosidase, and cytoprotective effects (anti-Alzheimer, antihemolytic, sun protection) (Table 1, Figure 6). The anticancer activity is the most adopted biological assay in saponins and evaluated in most of the scaffolds except quillaic acid- and ursane-type saponins. Oleanane-saponins exhibited antitumor cytotoxicity in the range of $\mathrm{IC}_{50}=0.5-7.6 \mu \mathrm{M}$ against various type of cancer cells in vitro, including cervical cancer (SMMC-7721, SGC-7901), lung cancer (NCI-H460, A549), colorectal cancer (HCT-116, HT-29), astrocytoma (U251), ovary cancer (SKOV-3), breast cancer (MCF-7), prostate cancer (PC-3), liver cancer (HepG2), leukemia (HL-60), and lymphoma (U937). The in vivo mice study revealed the tumor regression activity in H22 xenograft and MCF-7 xenograft models. The proposed anticancer cytotoxicity pathways in oleanane-saponin involved mitochondrial-dependent intrinsic apoptosis [31,35], apoptosis-ferroptosis-M2-TAM polarization [30], PI3K/Akt/mTOR pathway [21], and G1 cell cycle arrest [45]. Lupane-saponins were found to exhibit in vitro antitumor cytotoxicity in $\mathrm{IC}_{50}=0.9-5.0 \mu \mathrm{M}$ in colorectal cancer (DLD-1), breast cancer (MCF-7), leukemia (CEM), cervical cancer (HeLa), and melanoma (G-361); >100 and 1.3 $\mu \mathrm{M}$ in normal WS-1 and BJ cells, respectively. Cancer cell death was reported to be related to induced ROS production and decreased mitochondrial membrane potential, leading to apoptosis and DNA fragmentation [97]. Dammarane-saponins were found to exhibit anti-HeLa cytotoxicity with $\mathrm{IC}_{50}=4.6 \mu \mathrm{M}$. Cholestane-saponins exhibited antitumor cytotoxicity in the broad range of $\mathrm{IC}_{50}=0.0012-13.0 \mu \mathrm{M}$ in colorectal cancer (HCT-116), lung cancer (NCI-H1975), pancreatic cancer (Capan2, SW1990), neuroblastoma (SK-N-SH), cervical cancer (BGC823), liver cancer (HepG2), acute T cell leukemia (Jurkat, CCRF), and 0.16 $\mu \mathrm{M}$ in normal CRL1999 cells. One of the anticancer cytotoxicity was related to apoptotic Golgi responses through the CREB3-ARF4 pathway [64]. Spirostane-saponins were active toward HepG2 and MCF-7 with $\mathrm{IC}_{50}=2.7$ and $4.6 \mu \mathrm{M}$, respectively. Cardenolide-saponins showed nanomolar range $\mathrm{IC}_{50}$ in lung cancer (NCI-H460), breast cancer (MCF-7, MDA-MB-231), cervical cancer (HeLa), glioblastoma (U87), and liver cancer (HepG2), and no toxicity in normal HEK293T and NIH-3T3 cells at $3 \mu \mathrm{M}$. The cytotoxicity of cardenolide-saponin was found to involve DNA-damage upregulation, causing the induction process of apoptosis [72].

Anti-infection activities were found in oleanane-, hederagenin-, ursane-, lupane-, and spirostane-type saponins. Oleanane-saponins exhibited anti-H5N1 influenza virus activity with $\mathrm{IC}_{50}=4.05 \mu \mathrm{M}$ and low toxicity to Madin-Darby canine kidney (MDCK) cells $(92.7 \mu \mathrm{M})[39,40]$. As for antileishmanial assay, oleanane-saponins exhibited $\mathrm{ED}_{50}$ against axenic L. mexicana amastigotes as 6.0 and $29.7 \mu \mathrm{M}$ to the macrophage, which was not selective enough and needed further optimization [46]. In ursane-saponins, anti-H5N1 influenza virus activity was found, exhibiting $\mathrm{IC}_{50}=4.05 \mu \mathrm{M}$ accompanied with a low toxicity to MDCK cells $(>950 \mu \mathrm{M})$ [50]. Lupane-saponins were effective in inhibiting the growth of Staphylococcus aureus, and the MIC value was $7.8 \mu \mathrm{g} / \mathrm{mL}[56,57]$. Spirostane-saponins also showed anti-infection activity against Candida, Staphylococcus, Enterococcus, and Bacillus species in the range of $2-8 \mu \mathrm{M} / \mathrm{mL}$ [68]. 


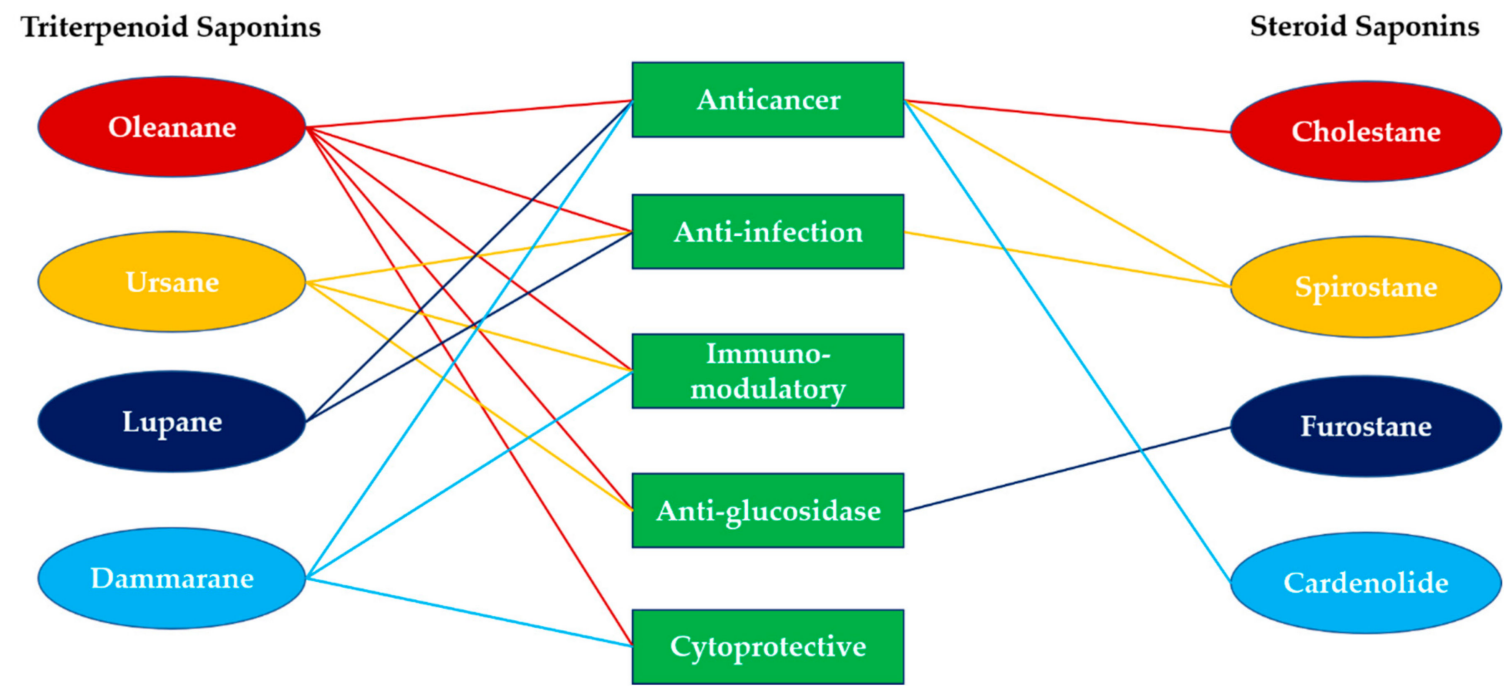

Figure 6. Summary of the biological and pharmacological activities of synthetic saponins.

The saponins with immunomodulatory effects were categorized into upregulation and downregulation. Immune upregulation activities were majorly evaluated in quillaic-saponins, which were extensively studied for the enhancement of serum IgG production compared to GPI-0100 and QS-21 for the development of vaccine adjuvants [47-49]. As for immune downregulation activities, ursane-saponins were able to protect $\mathrm{H} 9 \mathrm{c} 2$ cardiomyocytes from $\mathrm{H}_{2} \mathrm{O}_{2}$-induced apoptosis in a dose-dependent manner $(0.02-0.5 \mu \mathrm{g} / \mathrm{mL})$ through the inhibition of ROS generation and maintenance of mitochondrial membrane potential which were possibly related to the binding of Hsp90AB1 [52,89], and prevented NO overproduction induced by lipopolysaccharides (LPSs) in macrophages with $\mathrm{EC}_{50}=9.8 \mu \mathrm{M}$ [53]; dammarane-saponins were found to be effective in reducing serum IgE levels and airway resistance in an OVA-induced asthmatic mouse model [60]. The activity of glucosidase inhibition was evaluated in oleanane-, ursane-, and furostane-type saponins. Oleanane-, ursane-, furostane-saponins were able to inhibit $\alpha$-glucosidase with $\mathrm{IC}_{50}=9.2,448,96 \mu \mathrm{M}$, respectively, and the positive control, acarbose, was found to inhibit $\alpha$-glucosidase in the 500-1000 $\mu \mathrm{M}$ range $[41,51,69]$. Cytoprotective effects were found in oleanane-saponins for the protection of neuron cells from $\mathrm{H}_{2} \mathrm{O}_{2}$ - and $\mathrm{A} \beta_{1-42}$-induced injury [38]; dammarane-saponins for the protection of $\mathrm{HaCaT}$ cells from sunlight by increased sun protection factor (SPF) rating [61] and prevention of 2, 2'-azobis(2-methylpropionamidine) dihydrochloride (AAPH)-induced hemolysis in rabbit erythrocytes [59].

\section{Conclusions}

The biological and pharmacological activities of synthetic saponins in recent studies were collected and categorized with the saponins' structural characteristics. More detailed studies employing state-of-the-art biological experiments are necessary to understand the detailed mechanism of saponins in multiple disease models. By summarizing the SAR studies of synthetic saponins, we expect to help scientists working in this field to have a deeper understanding of the relationship between the structure and biological activity of synthetic saponins and hope to provide fruitful information for the development of saponin-based bioactive compounds.

Author Contributions: Y.-P.J. wrote this manuscript. P.-H.L. provided the professional guidance and financial support for this manuscript. All authors have read and agreed to the published version of the manuscript.

Funding: This research received no external funding.

Acknowledgments: This research was financially supported by the Ministry of Science and Technology (MOST 107-2320-B-002-019-MY3; 104-2320-B-002-008-MY3). Y.-P.J. has a scholarship supported by the Program of Research Performance Enhancement via Students Entering PhD Programs Straight from an Undergraduate/Master's Program from National Taiwan University. 
Conflicts of Interest: The authors declare no conflict of interest.

\section{References}

1. Abe, I.; Rohmer, M.; Prestwich, G.D. Enzymatic Cyclization of Squalene and Oxidosqualene to Sterols and Triterpenes. Chem. Rev. 1993, 93, 2189-2206. [CrossRef]

2. Vincken, J.P.; Heng, L.; de Groot, A.; Gruppen, H. Saponins, Classification and Occurrence in the Plant Kingdom. Phytochemistry 2007, 68, 275-297. [CrossRef] [PubMed]

3. Lorent, J.H.; Quetin-Leclercq, J.; Mingeot-Leclercq, M.P. The Amphiphilic Nature of Saponins and Their Effects on Artificial and Biological Membranes and Potential Consequences for Red Blood and Cancer Cells. Org. Biomol. Chem. 2014, 12, 8803-8822. [CrossRef] [PubMed]

4. Papadopoulou, K.; Melton, R.E.; Leggett, M.; Daniels, M.J.; Osbourn, A.E. Compromised Disease Resistance in Saponin-Deficient Plants. Proc. Natl. Acad. Sci. USA 1999, 96, 12923-12928. [CrossRef] [PubMed]

5. Biswas, T.; Dwivedi, U.N. Plant Triterpenoid Saponins: Biosynthesis, in Vitro Production, and Pharmacological Relevance. Protoplasma 2019, 256, 1463-1486. [CrossRef] [PubMed]

6. Yang, Y.; Laval, S.; Yu, B. Chemical Synthesis of Saponins. Adv. Carbohydr. Chem. Biochem. 2014, 71, 137-226. [CrossRef]

7. Xiao, G.; Shao, X.; Zhu, D.; Yu, B. Chemical Synthesis of Marine Saponins. Nat. Prod. Rep. 2019, 36, 769-787. [CrossRef]

8. Lin, T.S.; Tsai, W.T.; Liang, P.H. Rearrangement Reactions in the Fluorination of D-Glucopyranoside at the C-4 Position by Dast. Tetrahedron 2016, 72, 5571-5577. [CrossRef]

9. Lu, Y.J.; Lai, Y.H.; Lin, Y.Y.; Wang, Y.C.; Liang, P.H. 2-O-N-Benzylcarbamoyl as a Protecting Group to Promote Beta-Selective Glycosylation and Its Applications in the Stereoselective Synthesis of Oligosaccharides. J. Org. Chem. 2018, 83, 3688-3701. [CrossRef]

10. Hsieh, M.H.; Hung, J.T.; Liw, Y.W.; Lu, Y.J.; Wong, C.H.; Yu, A.L.; Liang, P.H. Synthesis and Evaluation of Acyl-Chain- and Galactose-6"-Modified Analogues of Alpha-Galcer for Nkt Cell Activation. ChemBioChem 2012, 13, 1689-1697. [CrossRef]

11. Lin, T.S.; Liw, Y.W.; Song, J.S.; Hsieh, T.C.; Yeh, H.W.; Hsu, L.C.; Lin, C.J.; Wu, S.H.; Liang, P.H. Synthesis and Biological Evaluation of Novel C-Aryl D-Glucofuranosides as Sodium-Dependent Glucose Co-Transporter 2 Inhibitors. Bioorg. Med. Chem. 2013, 21, 6282-6291. [CrossRef] [PubMed]

12. Wang, H.W.; Jiang, P.L.; Lin, S.F.; Lin, H.J.; Ou, K.L.; Deng, W.P.; Lee, L.W.; Huang, Y.Y.; Liang, P.H.; Liu, D.Z. Application of Galactose-Modified Liposomes as a Potent Antigen Presenting Cell Targeted Carrier for Intranasal Immunization. Acta Biomater. 2013, 9, 5681-5688. [CrossRef]

13. Wang, Y.H.; Yeh, H.W.; Wang, H.W.; Yu, C.C.; Guh, J.H.; Liu, D.Z.; Liang, P.H. Synthesis of a Chlorogenin Glycoside Library Using an Orthogonal Protecting Group Strategy. Carbohydr. Res. 2013, 375, 118-135. [CrossRef] [PubMed]

14. Zeng, Y.B.; Hsiao, H.M.; Chan, S.H.; Wang, Y.H.; Lin, Y.Y.; Kuo, Y.H.; Guh, J.H.; Liang, P.H. Synthesis and Anti-Cancer Activity of a Glycosyl Library of N-Acetylglucosamine-Bearing Oleanolic Acid. Mol. Divers. 2014, 18, 13-23. [CrossRef] [PubMed]

15. Chen, K.T.; Huang, D.Y.; Chiu, C.H.; Lin, W.W.; Liang, P.H.; Cheng, W.C. Synthesis of Diverse N-Substituted Muramyl Dipeptide Derivatives and Their Use in a Study of Human Nod2 Stimulation Activity. Chem. Eur. J. 2015, 21, 11984-11988. [CrossRef] [PubMed]

16. Yeh, H.W.; Lin, T.S.; Wang, H.W.; Cheng, H.W.; Liu, D.Z.; Liang, P.H. S-Linked Sialyloligosaccharides Bearing Liposomes and Micelles as Influenza Virus Inhibitors. Org. Biomol. Chem. 2015, 13, 11518-11528. [CrossRef] [PubMed]

17. Cheng, H.W.; Wang, H.W.; Wong, T.Y.; Yeh, H.W.; Chen, Y.C.; Liu, D.Z.; Liang, P.H. Synthesis of S-Linked Neuac-Alpha(2-6)-Di-Lacnac Bearing Liposomes for H1n1 Influenza Virus Inhibition Assays. Bioorg. Med. Chem. 2018, 26, 2262-2270. [CrossRef] [PubMed]

18. Lin, Y.Y.; Chan, S.H.; Juang, Y.P.; Hsiao, H.M.; Guh, J.H.; Liang, P.H. Design, Synthesis and Cytotoxic Activity of N-Modified Oleanolic Saponins Bearing a Glucosamine. Eur. J. Med. Chem. 2018, 143, 1942-1958. [CrossRef] [PubMed] 
19. Wong, T.Y.; Tsai, M.S.; Hsu, L.C.; Lin, S.W.; Liang, P.H. Traversal of the Blood-Brain Barrier by Cleavable L-Lysine Conjugates of Apigenin. J. Agric. Food Chem. 2018, 66, 8124-8131. [CrossRef]

20. Hng, Y.; Lin, M.H.; Lin, T.S.; Liu, I.C.; Lin, I.C.; Lu, Y.L.; Chang, C.N.; Chiu, P.F.; Tsai, K.C.; Chen, M.J.; et al. Design and Synthesis of 3-Benzylaminocoumarin-7-O-Sulfamate Derivatives as Steroid Sulfatase Inhibitors. Bioorg. Chem. 2020, 96, 103618. [CrossRef]

21. Juang, Y.P.; Lin, Y.Y.; Chan, S.H.; Chang, C.K.; Shie, J.J.; Hsieh, Y.S.Y.; Guh, J.H.; Liang, P.H. Synthesis, Distribution Analysis and Mechanism Studies of N-Acyl Glucosamine-Bearing Oleanolic Saponins. Bioorg. Chem. 2020, 99, 103835. [CrossRef] [PubMed]

22. Lin, T.S.; Hsieh, C.H.; Kuo, C.; Juang, Y.P.; Hsieh, Y.S.Y.; Chiang, H.S.; Hung, S.C.; Jiang, C.C.; Liang, P.H. Sulfation Pattern of Chondroitin Sulfate in Human Osteoarthritis Cartilages Reveals a Lower Level of Chondroitin-4-Sulfate. Carbohydr. Polym. 2020, 229, 115496. [CrossRef] [PubMed]

23. Pollier, J.; Goossens, A. Oleanolic Acid. Phytochemistry 2012, 77, 10-15. [CrossRef] [PubMed]

24. Lacaille-Dubois, M.A. Updated Insights into the Mechanism of Action and Clinical Profile of the Immunoadjuvant Qs-21: A Review. Phytomedicine 2019, 60, 152905. [CrossRef]

25. Xu, X.H.; Li, T.; Fong, C.M.; Chen, X.; Chen, X.J.; Wang, Y.T.; Huang, M.Q.; Lu, J.J. Saponins from Chinese Medicines as Anticancer Agents. Molecules 2016, 21, 1326. [CrossRef]

26. Yu, M.; Si, L.; Wang, Y.; Wu, Y.; Yu, F.; Jiao, P.; Shi, Y.; Wang, H.; Xiao, S.; Fu, G.; et al. Discovery of Pentacyclic Triterpenoids as Potential Entry Inhibitors of Influenza Viruses. J. Med. Chem. 2014, 57, 10058-10071. [CrossRef]

27. Bottcher, S.; Drusch, S. Saponins-Self-Assembly and Behavior at Aqueous Interfaces. Adv. Colloid Interface Sci. 2017, 243, 105-113. [CrossRef]

28. Zheng, S.; Wang, Y.; Liu, H.; Chang, W.; Xu, Y.; Lin, F. Prediction of Hemolytic Toxicity for Saponins by Machine-Learning Methods. Chem. Res. Toxicol. 2019, 32, 1014-1026. [CrossRef]

29. Sui, J.J.; Zhou, W.H.; Liu, D.Y.; Li, M.Q.; Sun, J.S. Highly Efficient Synthesis of Bioactive Oleanane-Type Saponins. Carbohydr. Res. 2017, 452, 43-46. [CrossRef]

30. Wei, G.; Sun, J.; Luan, W.; Hou, Z.; Wang, S.; Cui, S.; Cheng, M.; Liu, Y. Natural Product Albiziabioside a Conjugated with Pyruvate Dehydrogenase Kinase Inhibitor Dichloroacetate to Induce Apoptosis-Ferroptosis-M2-Tams Polarization for Combined Cancer Therapy. J. Med. Chem. 2019, 62, 8760-8772. [CrossRef]

31. Wei, G.; Cui, S.; Luan, W.; Wang, S.; Hou, Z.; Liu, Y.; Liu, Y.; Cheng, M. Natural Product-Based Design, Synthesis and Biological Evaluation of Albiziabioside a Derivatives That Selectively Induce Hct116 Cell Death. Eur. J. Med. Chem. 2016, 113, 92-101. [CrossRef] [PubMed]

32. Fang, Y.; Wang, R.; He, M.; Huang, H.; Wang, Q.; Yang, Z.; Li, Y.; Yang, S.; Jin, Y. Nitric Oxide-Donating Derivatives of Hederacolchiside A1: Synthesis and Biological Evaluation in Vitro and in Vivo as Potential Anticancer Agents. Bioorg. Med. Chem. Lett. 2017, 27, 98-101. [CrossRef]

33. Fang, Y.; Yang, Z.; Ouyang, H.; Wang, R.; Li, J.; Huang, H.; Jin, Y.; Feng, Y.; Yang, S. Synthesis and Biological Evaluation of Hederacolchiside A1 Derivatives as Anticancer Agents. Bioorg. Med. Chem. Lett. 2016, 26, 4576-4579. [CrossRef] [PubMed]

34. Wang, L.; Wang, Z.; Su, S.; Xing, Y.; Li, Y.; Li, M.; Liu, J.; Yang, S. Synthesis and Cytotoxicity of Oleanolic Acid Trisaccharide Saponins. Carbohydr. Res. 2017, 442, 9-16. [CrossRef]

35. Li, H.N.; Wang, H.; Wang, Z.P.; Yan, H.N.; Zhang, M.; Liu, Y.; Cheng, M.S. Synthesis, Antitumor Activity Evaluation and Mechanistic Study of Novel Hederacolchiside A1 Derivatives Bearing an Aryl Triazole Moiety. Bioorg. Med. Chem. 2018, 26, 4025-4033. [CrossRef] [PubMed]

36. Chen, Z.; Duan, H.; Wang, M.; Han, L.; Liu, Y.; Zhu, Y.; Yang, S. Synthesis, Cytotoxicity and Haemolytic Activity of Pulsatilla Saponin a, D Derivatives. Bioorg. Med. Chem. Lett. 2015, 25, 2550-2554. [CrossRef] [PubMed]

37. Wei, G.; Wang, S.; Cui, S.; Guo, J.; Liu, Y.; Liu, Y.; Cheng, M. Synthesis and Evaluation of the Anticancer Activity of Albiziabioside a and Its Analogues as Apoptosis Inducers against Human Melanoma Cells. Org. Biomol. Chem. 2014, 12, 5928-5935. [CrossRef] 
38. Li, H.N.; Liu, Y.; Zhang, Z.P.; Wang, Z.P.; Hao, J.Z.; Li, F.R.; Fan, Z.F.; Zou, L.B.; Cheng, M.S. Synthesis, Biological Evaluation and Structure-Activity Relationship Studies of Hederacolchiside E and Its Derivatives as Potential Anti-Alzheimer Agents. Eur. J. Med. Chem. 2018, 143, 376-389. [CrossRef]

39. Song, G.; Shen, X.; Li, S.; Li, Y.; Si, H.; Fan, J.; Li, J.; Gao, E.; Liu, S. Structure-Activity Relationships of 3-O-Beta-Chacotriosyl Oleanane-Type Triterpenoids as Potential H5n1 Entry Inhibitors. Eur. J. Med. Chem. 2016, 119, 109-121. [CrossRef]

40. Li, S.; Jia, X.; Shen, X.; Wei, Z.; Jiang, Z.; Liao, Y.; Guo, Y.; Zheng, X.; Zhong, G.; Song, G. Structure-Activity Relationships of 3-O-Beta-Chacotriosyl Oleanic Acid Derivatives as Entry Inhibitors for Highly Pathogenic H5n1 Influenza Virus. Bioorg. Med. Chem. 2017, 25, 4384-4396. [CrossRef]

41. Liu, Q.C.; Guo, T.T.; Li, F.H.; Li, D. Concise Synthesis of a New Triterpenoid Saponin from the Roots of Gypsophila Oldhamiana and Its Derivatives as Alpha-Glucosidase Inhibitors. New J. Chem. 2016, 40, 9537-9549. [CrossRef]

42. Shirahata, T.; Nagai, T.; Hirata, N.; Yokoyama, M.; Katsumi, T.; Konishi, N.; Nishino, T.; Makino, K.; Yamada, H.; Kaji, E.; et al. Syntheses and Mucosal Adjuvant Activity of Simplified Oleanolic Acid Saponins Possessing Cinnamoyl Ester. Bioorg. Med. Chem. 2017, 25, 1747-1755. [CrossRef] [PubMed]

43. Nakamura, R.; Shirahata, T.; Konishi, N.; Takanezawa, Y.; Sone, Y.; Uraguchi, S.; Kobayashi, Y.; Kiyono, M. Oleanolic Acid 3-Glucoside, a Synthetic Oleanane-Type Saponin, Alleviates Methylmercury Toxicity in Vitro and in Vivo. Toxicology 2019, 417, 15-22. [CrossRef] [PubMed]

44. Abdel-Kader, M.; Hoch, J.; Berger, J.M.; Evans, R.; Miller, J.S.; Wisse, J.H.; Mamber, S.W.; Dalton, J.M.; Kingston, D.G.I. Two Bioactive Saponins from Albizia Subdimidiata from the Suriname Rainforest. J. Nat. Prod. 2001, 64, 536-539. [CrossRef] [PubMed]

45. Fang, Y.; Hu, D.; Li, H.; Hu, J.; Liu, Y.; Li, Z.; Xu, G.; Chen, L.; Jin, Y.; Yang, S.; et al. Synthesis, Biological Evaluation, and Mode of Action of Pulsatilla Saponin D Derivatives as Promising Anticancer Agents. Front. Pharmacol. 2019, 10, 1208. [CrossRef]

46. Anderson, O.; Beckett, J.; Briggs, C.C.; Natrass, L.A.; Cranston, C.F.; Wilkinson, E.J.; Owen, J.H.; Williams, R.M.; Loukaidis, A.; Bouillon, M.E.; et al. An Investigation of the Antileishmanial Properties of Semi-Synthetic Saponins. RSC Med. Chem. 2020, 11, 833-842. [CrossRef]

47. Wang, P.F.; Devalankar, D.A.; Dai, Q.P.; Zhang, P.; Michalek, S.M. Synthesis and Evaluation of Qs-21-Based Immunoadjuvants with a Terminal-Functionalized Side Chain Incorporated in the West Wing Trisaccharide. J. Org. Chem. 2016, 81, 9560-9566. [CrossRef]

48. Wang, P.; Ding, X.; Kim, H.; Michalek, S.M.; Zhang, P. Structural Effect on Adjuvanticity of Saponins. J. Med. Chem. 2020, 63, 3290-3297. [CrossRef]

49. Skalamera, D.; Kim, H.; Zhang, P.; Michalek, S.M.; Wang, P. Impact of C28 Oligosaccharide on Adjuvant Activity of Qs-7 Analogues. J. Org. Chem. 2020, in press. [CrossRef]

50. Liao, Y.; Chen, L.; Li, S.; Cui, Z.N.; Lei, Z.; Li, H.; Liu, S.; Song, G. Structure-Aided Optimization of 3-O-Beta-Chacotriosyl Ursolic Acid as Novel H5n1 Entry Inhibitors with High Selective Index. Bioorg. Med. Chem. 2019, 27, 4048-4058. [CrossRef]

51. Xu, J.C.; Nie, X.L.; Hong, Y.P.; Jiang, Y.; Wu, G.Q.; Yin, X.L.; Wang, C.R.; Wang, X.Q. Synthesis of Water Soluble Glycosides of Pentacyclic Dihydroxytriterpene Carboxylic Acids as Inhibitors of Alpha-Glucosidase. Carbohydr. Res. 2016, 424, 42-53. [CrossRef] [PubMed]

52. Tian, Y.; Du, Y.Y.; Shang, H.; Wang, M.; Sun, Z.H.; Wang, B.Q.; Deng, D.; Wang, S.; Xu, X.D.; Sun, G.B.; et al. Calenduloside E Analogues Protecting H9c2 Cardiomyocytes against H2o2-Induced Apoptosis: Design, Synthesis and Biological Evaluation. Front. Pharmacol. 2017, 8, 862. [CrossRef]

53. Sylla, B.; Lavoie, S.; Legault, J.; Gauthier, C.; Pichette, A. Synthesis, Cytotoxicity and Anti-Inflammatory Activity of Rhamnose-Containing Ursolic and Betulinic Acid Saponins. RSC Adv. 2019, 9, 39743-39757. [CrossRef]

54. Myszka, H.; Grzywacz, D.; Zdrowowicz, M.; Spisz, P.; Butowska, K.; Rak, J.; Piosik, J.; Jaskiewicz, M.; Kamysz, W.; Liberek, B. Design, Synthesis and Biological Evaluation of Betulin-3-Y1 2-Amino-2-Deoxy-Beta-D-Glycopyranosides. Bioorg. Chem. 2020, 96, 103568. [CrossRef] [PubMed]

55. Korda, A.; Rarova, L.; Pakulski, Z.; Strnad, M.; Oklestkova, J.; Kuczynska, K.; Cmoch, P.; Gwardiak, K.; Karczewski, R. New Lupane Bidesmosides Exhibiting Strong Cytotoxic Activities in Vitro. Bioorg. Chem. 2020, 100, 103868. [CrossRef] [PubMed] 
56. Strobykina, I.Y.; Garifullin, B.F.; Sharipova, R.R.; Voloshina, A.D.; Strobykina, A.S.; Dobrynin, A.B.; Kataev, V.E. Synthesis and Antimicrobial Activity of Dihydrobetulin N-Acetylglucosaminides. Chem. Nat. Compd. 2017, 53, 1101-1106. [CrossRef]

57. Strobykina, I.Y.; Garifullin, B.F.; Strobykina, A.S.; Voloshina, A.D.; Sharipova, R.R.; Kataev, V.E. Allobetulin N-Acetylglucosaminide. Synthesis and Antimicrobial Activity. Russ. J. Gene. Chem. 2017, 87, 890-893. [CrossRef]

58. Yang, J.; Li, X.W.; Sun, T.; Gao, Y.; Chen, Y.X.; Jin, Y.R.; Li, Y. Semisynthesis and Bioactive Evaluation of Oxidized Products from 20(S)-Ginsenoside Rg(3), Rh-2, Protopanaxadiol (Ppd) and Their 20(R)-Epimers as Cytotoxic Agents. Steroids 2016, 106, 26-34. [CrossRef]

59. Li, M.M.; Chen, Y.P.; Zhang, P.F.; Zhang, L.; Zhou, R.; Xu, Y.; Ding, H.D.; Wang, Q.J.; Wang, Z.C. Semi-Synthesis of Twelve Known 20z/E Pseudo-Ginsenosides and Their Comparative Study of Antioxidative Activity in Free Radical Induced Hemolysis of Rabbit Erythrocytes. Chem. Pharm. Bull. 2018, 66, 535-540. [CrossRef]

60. Ren, S.; Liu, R.; Wang, Y.; Ding, N.; Li, Y. Synthesis and Biological Evaluation of Ginsenoside Compound K Analogues as a Novel Class of Anti-Asthmatic Agents. Bioorg. Med. Chem. Lett. 2019, 29, 51-55. [CrossRef]

61. Markus, J.; Mathiyalagan, R.; Kim, Y.J.; Han, Y.; Jimenez-Perez, Z.E.; Veronika, S.; Yang, D.C. Synthesis of Hyaluronic Acid or O-Carboxymethyl Chitosan-Stabilized Zno-Ginsenoside Rh2 Nanocomposites Incorporated with Aqueous Leaf Extract of Dendropanax Morbifera Leveille: In Vitro Studies as Potential Sunscreen Agents. New J. Chem. 2019, 43, 9188-9200. [CrossRef]

62. Liu, C.; Wang, A.P.; Jin, L.L.; Guo, Y.S.; Li, Y.; Zhao, Z.H.; Lei, P.S. Synthesis, Conformational Analysis and Sar Research of Osw-1 Analogues. Tetrahedron 2016, 72, 4091-4102. [CrossRef]

63. Sun, L.J.; Wang, R.N.; Wang, X.B.; Dang, Y.J.; Li, W.; Yu, B. Synthesis and Antiproliferative Activities of Osw-1 Analogues Bearing 2-Acylamino-Xylose Residues. Org. Chem. Front. 2019, 6, 2385-2391. [CrossRef]

64. Kimura, M.; Sasaki, K.; Fukutani, Y.; Yoshida, H.; Ohsawa, I.; Yohda, M.; Sakurai, K. Anticancer Saponin Osw-1 Is a Novel Class of Selective Golgi Stress Inducer. Bioorg. Med. Chem. Lett. 2019, 29, 1732-1736. [CrossRef]

65. Malabed, R.; Hanashima, S.; Murata, M.; Sakurai, K. Interactions of Osw-1 with Lipid Bilayers in Comparison with Digitonin and Soyasaponin. Langmuir 2020, 36, 3600-3610. [CrossRef]

66. Chan, S.H.; Liang, P.H.; Guh, J.H. An Integrated Approach to Elucidate Signaling Pathways of Dioscin-Induced Apoptosis, Energy Metabolism and Differentiation in Acute Myeloid Leukemia. Naunyn-Schmiedeberg's Arch. Pharmacol. 2018, 391, 587-602. [CrossRef]

67. Li, G.L.; Xu, H.J.; Xu, S.H.; Wang, W.W.; Yu, B.Y.; Zhang, J. Synthesis of Tigogenin Meon-Neoglycosides and Their Antitumor Activity. Fitoterapia 2018, 125, 33-40. [CrossRef]

68. Grzywacz, D.; Paduszynska, M.; Norkowska, M.; Kamysz, W.; Myszka, H.; Liberek, B. N-Aminoacyl and N-Hydroxyacyl Derivatives of Diosgenyl 2-Amino-2-Deoxy-Beta-D-Glucopyranoside: Synthesis, Antimicrobial and Hemolytic Activities. Bioorg. Med. Chem. 2019, 27, 114923. [CrossRef]

69. Wang, P.; Hao, J.J.; Zhang, X.L.; Wang, C.; Guan, H.S.; Li, M. Synthesis of Furostanol Glycosides: Discovery of a Potent Alpha-Glucosidase Inhibitor. Org. Biomol. Chem. 2016, 14, 9362-9374. [CrossRef]

70. Li, X.S.; Ren, Y.C.; Sao, Y.Z.; Liu, J.; Zhang, X.K.; Zhang, Y.W.; Sun, X.L.; Yao, X.S.; Tang, J.S. Synthesis of C-3-Neoglycosides of Digoxigenin and Their Anticancer Activities. Eur. J. Med. Chem. 2018, 145, 252-262. [CrossRef]

71. Urabe, D.; Nakagawa, Y.; Mukai, K.; Fukushima, K.; Aoki, N.; Itoh, H.; Nagatomo, M.; Inoue, M. Total Synthesis and Biological Evaluation of 19-Hydroxysarmentogenin-3-O-Alpha-L-Rhamnoside, Trewianin, and Their Aglycons. J. Org. Chem. 2018, 83, 13888-13910. [CrossRef] [PubMed]

72. Khatri, H.R.; Bhattarai, B.; Kaplan, W.; Li, Z.Z.; Long, M.J.C.; Aye, Y.; Nagorny, P. Modular Total Synthesis and Cell-Based Anticancer Activity Evaluation of Ouabagenin and Other Cardiotonic Steroids with Varying Degrees of Oxygenation. J. Am. Chem. Soc. 2019, 141, 4849-4860. [CrossRef] [PubMed]

73. Tong, X.; Han, L.; Duan, H.; Cui, Y.; Feng, Y.; Zhu, Y.; Chen, Z.; Yang, S. The Derivatives of Pulsatilla Saponin a, a Bioactive Compound from Pulsatilla Chinensis: Their Synthesis, Cytotoxicity, Haemolytic Toxicity and Mechanism of Action. Eur. J. Med. Chem. 2017, 129, 325-336. [CrossRef]

74. Chen, Z.; Duan, H.; Tong, X.; Hsu, P.; Han, L.; Morris-Natschke, S.L.; Yang, S.; Liu, W.; Lee, K.H. Cytotoxicity, Hemolytic Toxicity, and Mechanism of Action of Pulsatilla Saponin D and Its Synthetic Derivatives. J. Nat. Prod. 2018, 81, 465-474. [CrossRef] [PubMed] 
75. Marciani, D.J. Elucidating the Mechanisms of Action of Saponin-Derived Adjuvants. Trends Pharmacol. Sci. 2018, 39, 573-585. [CrossRef] [PubMed]

76. Wang, P.F.; Kim, Y.J.; Navarro-Villalobos, M.; Rohde, B.D.; Gin, D.Y. Synthesis of the Potent Immunostimulatory Adjuvant Qs-21a. J. Am. Chem. Soc. 2005, 127, 3256-3257. [CrossRef] [PubMed]

77. Fernandez-Tejada, A.; Tan, D.S.; Gin, D.Y. Development of Improved Vaccine Adjuvants Based on the Saponin Natural Product Qs-21 through Chemical Synthesis. Acc. Chem. Res. 2016, 49, 1741-1756. [CrossRef] [PubMed]

78. Wang, P.F.; Dai, Q.P.; Thogaripally, P.; Zhang, P.; Michalek, S.M. Synthesis of Qs-21-Based Immunoadjuvants. J. Org. Chem. 2013, 78, 11525-11534. [CrossRef]

79. Wang, P.; Skalamera, D.; Sui, X.; Zhang, P.; Michalek, S.M. Synthesis and Evaluation of a Qs-17/18-Based Vaccine Adjuvant. J. Med. Chem. 2019, 62, 1669-1676. [CrossRef]

80. Wang, P.; Skalamera, D.; Sui, X.; Zhang, P.; Michalek, S.M. Synthesis and Evaluation of Qs-7-Based Vaccine Adjuvants. ACS Infect. Dis. 2019, 5, 974-981. [CrossRef]

81. Wang, P.; Ding, X.; Kim, H.; Skalamera, D.; Michalek, S.M.; Zhang, P. Vaccine Adjuvants Derivatized from Momordica Saponins I and Ii. J. Med. Chem. 2019, 62, 9976-9982. [CrossRef] [PubMed]

82. Ghirardello, M.; Ruiz-de-Angulo, A.; Sacristan, N.; Barriales, D.; Jimenez-Barbero, J.; Poveda, A.; Corzana, F.; Anguita, J.; Fernandez-Tejada, A. Exploiting Structure-Activity Relationships of Qs-21 in the Design and Synthesis of Streamlined Saponin Vaccine Adjuvants. Chem. Commun. 2020, 56, 719-722. [CrossRef] [PubMed]

83. Wozniak, L.; Skapska, S.; Marszalek, K. Ursolic Acid-A Pentacyclic Triterpenoid with a Wide Spectrum of Pharmacological Activities. Molecules 2015, 20, 20614-20641. [CrossRef] [PubMed]

84. Hussain, H.; Green, I.R.; Ali, I.; Khan, I.A.; Ali, Z.; Al-Sadi, A.M.; Ahmed, I. Ursolic Acid Derivatives for Pharmaceutical Use: A Patent Review (2012-2016). Expert Opin. Ther. Pat. 2017, 27, 1061-1072. [CrossRef]

85. Mlala, S.; Oyedeji, A.O.; Gondwe, M.; Oyedeji, O.O. Ursolic Acid and Its Derivatives as Bioactive Agents. Molecules 2019, 24, 2751. [CrossRef]

86. Song, G.P.; Shen, X.T.; Li, S.M.; Li, Y.B.; Liu, Y.P.; Zheng, Y.S.; Lin, R.H.; Fan, J.H.; Ye, H.M.; Liu, S.W. Structure-Activity Relationships of 3-O-Beta-Chacotriosyl Ursolic Acid Derivatives as Novel H5n1 Entry Inhibitors. Eur. J. Med. Chem. 2015, 93, 431-442. [CrossRef]

87. Li, H.; Chen, L.Z.; Li, S.M.; Liao, Y.X.; Wang, L.; Liu, Z.H.; Liu, S.W.; Song, G.P. Incorporation of Privileged Structures into 3-O-Beta-Chacotriosyl Ursolic Acid Can Enhance Inhibiting the Entry of the H5n1 Virus. Bioorg. Med. Chem. Lett. 2019, 29, 2675-2680. [CrossRef]

88. Li, S.; Jia, X.; Li, H.; Ye, Y.; Zhang, X.; Gao, Y.; Guo, G.; Liu, S.; Song, G. Structure-Aided Optimization of 3-O-Beta-Chacotriosyl Epiursolic Acid Derivatives as Novel H5n1 Virus Entry Inhibitors. Bioorg. Med. Chem. Lett. 2020, 30, 127518. [CrossRef]

89. Wang, S.; Tian, Y.; Zhang, J.Y.; Xu, H.B.; Zhou, P.; Wang, M.; Lu, S.B.; Luo, Y.; Wang, M.; Sun, G.B.; et al. Targets Fishing and Identification of Calenduloside E as Hsp90ab1: Design, Synthesis, and Evaluation of Clickable Activity-Based Probe. Front. Pharmacol. 2018, 9, 532. [CrossRef]

90. Tian, Y.; Wang, S.; Shang, H.; Wang, W.Q.; Wang, B.Q.; Zhang, X.; Xu, X.D.; Sun, G.B.; Sun, X.B. The Clickable Activity-Based Probe of Anti-Apoptotic Calenduloside E. Pharm. Biol. 2019, 57, 133-139. [CrossRef]

91. Zhao, G.; Yan, W.; Cao, D. Simultaneous Determination of Betulin and Betulinic Acid in White Birch Bark Using Rp-Hplc. J. Pharm. Biomed. Anal. 2007, 43, 959-962. [CrossRef] [PubMed]

92. Amiri, S.; Dastghaib, S.; Ahmadi, M.; Mehrbod, P.; Khadem, F.; Behrouj, H.; Aghanoori, M.R.; Machaj, F.; Ghamsari, M.; Rosik, J.; et al. Betulin and Its Derivatives as Novel Compounds with Different Pharmacological Effects. Biotechnol. Adv. 2020, 38, 107409. [CrossRef] [PubMed]

93. Chaturvedi, P.K.; Bhui, K.; Shukla, Y. Lupeol: Connotations for Chemoprevention. Cancer Lett. 2008, 263, 1-13. [CrossRef] [PubMed]

94. Rastogi, S.; Pandey, M.M.; Rawat, A.K.S. Medicinal Plants of the Genus Betula-Traditional Uses and a Phytochemical-Pharmacological Review. J. Ethnopharmacol. 2015, 159, 62-83. [CrossRef] [PubMed]

95. Udeani, G.O.; Zhao, G.M.; Geun Shin, Y.; Cooke, B.P.; Graham, J.; Beecher, C.W.; Kinghorn, A.D.; Pezzuto, J.M. Pharmacokinetics and Tissue Distribution of Betulinic Acid in Cd-1 Mice. Biopharm. Drug Dispos. 1999, 20, 379-383. [CrossRef]

96. Gauthier, C.; Legault, J.; Piochon-Gauthier, M.; Pichette, A. Advances in the Synthesis and Pharmacological Activity of Lupane-Type Triterpenoid Saponins. Phytochem. Rev. 2011, 10, 521-544. [CrossRef] 
97. Mihoub, M.; Pichette, A.; Sylla, B.; Gauthier, C.; Legault, J. Bidesmosidic Betulin Saponin Bearing L-Rhamnopyranoside Moieties Induces Apoptosis and Inhibition of Lung Cancer Cells Growth in Vitro and in Vivo. PLoS ONE 2018, 13, e0193386. [CrossRef]

98. Cmoch, P.; Korda, A.; Rarova, L.; Oklestkova, J.; Strnad, M.; Luboradzki, R.; Pakulski, Z. Synthesis and Structure-Activity Relationship Study of Cytotoxic Lupane-Type 3 Beta-O-Monodesmosidic Saponins with an Extended C-28 Side Chain. Tetrahedron 2014, 70, 2717-2730. [CrossRef]

99. Sidoryk, K.; Korda, A.; Rarova, L.; Oklestkova, J.; Strnad, M.; Cmoch, P.; Pakulski, Z.; Gwardiak, K.; Karczewski, R.; Luboradzki, R. Synthesis and Biological Activity of New Homolupanes and Homolupane Saponins. Tetrahedron 2015, 71, 2004-2012. [CrossRef]

100. Sidoryk, K.; Rarova, L.; Oklestkova, J.; Pakulski, Z.; Strnad, M.; Cmoch, P.; Luboradzki, R. Synthesis of 28a-Homoselenolupanes and 28a-Homoselenolupane Saponins. Org. Biomol. Chem. 2016, 14, 10238-10248. [CrossRef]

101. Sidoryk, K.; Korda, A.; Rarova, L.; Oklestkova, J.; Pakulski, Z.; Strnad, M.; Cmoch, P.; Gwardiak, K.; Karczewski, R. Synthesis and Cytotoxicity of 28a-Homothiolupanes and 28a-Homothiolupane Saponins. Eur. J. Org. Chem. 2016, 2016, 373-383. [CrossRef]

102. Piao, X.; Zhang, H.; Kang, J.P.; Yang, D.U.; Li, Y.; Pang, S.; Jin, Y.; Yang, D.C.; Wang, Y. Advances in Saponin Diversity of Panax Ginseng. Molecules 2020, 25, 3452. [CrossRef] [PubMed]

103. Atopkina, L.N.; Uvarova, N.I.; Elyakov, G.B. Simplified Preparation of the Ginsenoside-Rh-2 Minor Saponin from Ginseng. Carbohydr. Res. 1997, 303, 449-451. [CrossRef]

104. Liao, J.X.; Sun, J.S.; Niu, Y.M.; Yu, B. Synthesis of Ginsenoside Rh2 and Chikusetsusaponin-Lt8 Via Gold(I)-Catalyzed Glycosylation with a Glycosyl Ortho-Alkynylbenzoate as Donor. Tetrahedron Lett. 2011, 52, 3075-3078. [CrossRef]

105. Yu, J.; Sun, J.S.; Niu, Y.M.; Li, R.Y.; Liao, J.X.; Zhang, F.Y.; Yu, B. Synthetic Access toward the Diverse Ginsenosides. Chem. Sci. 2013, 4, 3899-3905. [CrossRef]

106. Huang, L.; Zou, C.; Liu, Y.H.; Li, R.; Duan, W.Y.; Du, R.A.; Yang, W.M. Progress in the Synthesis and Modification on Ginsenosides. Mini-Rev. Org. Chem. 2018, 15, 444-458. [CrossRef]

107. Qian, G.T.; Wang, Z.C.; Zhao, J.Y.; Li, D.D.; Gao, W.; Wang, B.H.; Sui, D.Y.; Qu, X.R.; Chen, Y.P. Synthesis and Anti-Cancer Cell Activity of Pseudo-Ginsenoside Rh2. Steroids 2014, 92, 1-6. [CrossRef]

108. Ding, H.D.; Chen, Y.P.; Chen, S.; Li, M.M.; Tan, Z.Y.; Lu, Z.Y.; Zhang, P.F.; Gao, W.; Xu, Y.; Xu, F.F.; et al. Semi-Synthesis and Cellular Effects of Three Different Ginsenosides Derived from Re, Rh-1, and Ppt. Chem. Nat. Compd. 2019, 55, 66-73. [CrossRef]

109. Kubo, S.; Mimaki, Y.; Terao, M.; Sashida, Y.; Nikaido, T.; Ohmoto, T. Acylated Cholestane Glycosides from the Bulbs of Ornithogalum-Saundersiae. Phytochemistry 1992, 31, 3969-3973. [CrossRef]

110. Tang, Y.P.; Li, N.G.; Duan, J.A.; Tao, W.W. Structure, Bioactivity, and Chemical Synthesis of Osw-1 and Other Steroidal Glycosides in the Genus Ornithogalum. Chem. Rev. 2013, 113, 5480-5514. [CrossRef]

111. Yamada, R.; Takeshita, T.; Hiraizumi, M.; Shinohe, D.; Ohta, Y.; Sakurai, K. Fluorescent Analog of Osw-1 and Its Cellular Localization. Bioorg. Med. Chem. Lett. 2014, 24, 1839-1842. [CrossRef] [PubMed]

112. Sakurai, K.; Takeshita, T.; Hiraizumi, M.; Yamada, R. Synthesis of Osw-1 Derivatives by Site-Selective Acylation and Their Biological Evaluation. Org. Lett. 2014, 16, 6318-6321. [CrossRef]

113. Yamada, R.; Hiraizumi, M.; Narita, S.; Sakurai, K. Two-Step Synthesis of a Clickable Photoaffinity Probe from an Anticancer Saponin Osw-1 and Its Photochemical Reactivity. Asian J. Org. Chem. 2016, 5, 330-334. [CrossRef]

114. Sakurai, K.; Hiraizumi, M.; Isogai, N.; Komatsu, R.; Shibata, T.; Ohta, Y. Synthesis of a Fluorescent Photoaffinity Probe of Osw-1 by Site-Selective Acylation of an Inactive Congener and Biological Evaluation. Chem. Commun. 2017, 53, 517-520. [CrossRef]

115. Hiraizumi, M.; Komatsu, R.; Shibata, T.; Ohta, Y.; Sakurai, K. Dissecting the Structural Basis for the Intracellular Delivery of Osw-1 by Fluorescent Probes. Org. Biomol. Chem. 2017, 15, 3568-3570. [CrossRef] [PubMed]

116. Malabed, R.; Hanashima, S.; Murata, M.; Sakurai, K. Sterol-Recognition Ability and Membrane-Disrupting Activity of Ornithogalum Saponin Osw-1 and Usual 3-O-Glycosyl Saponins. Biochim. Biophys. Acta Biomembr. 2017, 1859, 2516-2525. [CrossRef] 
117. Parama, D.; Boruah, M.; Kumari, Y.; Rana, V.; Banik, K.; Harsha, C.; Thakur, K.K.; Dutta, U.; Arya, A.; Mao, X.; et al. Diosgenin, a Steroidal Saponin, and Its Analogues: Effective Therapies against Different Chronic Diseases. Life Sci. 2020, 260, 118182. [CrossRef] [PubMed]

118. Song, G.; Yang, S.; Zhang, W.; Cao, Y.; Wang, P.; Ding, N.; Zhang, Z.; Guo, Y.; Li, Y. Discovery of the First Series of Small Molecule H5n1 Entry Inhibitors. J. Med. Chem. 2009, 52, 7368-7371. [CrossRef] [PubMed]

119. Wang, B.; Liu, Y.; Wang, Y.S.; Liu, X.; Cheng, M.S. Syntheses and Structure-Activity Relationship Studies of N-Substituted-Beta-D-Glucosaminides as Selective Cytotoxic Agents. Bioorg. Med. Chem. Lett. 2012, 22, 7110-7113. [CrossRef] [PubMed]

120. Zhang, R.; Huang, B.; Du, D.; Guo, X.; Xin, G.; Xing, Z.; Liang, Y.; Chen, Y.; Chen, Q.; He, Y.; et al. Anti-Thrombosis Effect of Diosgenyl Saponins in Vitro and in Vivo. Steroids 2013, 78, 1064-1070. [CrossRef]

121. Walczewska, A.; Grzywacz, D.; Bednarczyk, D.; Dawgul, M.; Nowacki, A.; Kamysz, W.; Liberek, B.; Myszka, H. N-Alkyl Derivatives of Diosgenyl 2-Amino-2-Deoxy-Beta-D-Glucopyranoside; Synthesis and Antimicrobial Activity. Beilstein J. Org. Chem. 2015, 11, 869-874. [CrossRef] [PubMed]

122. Myszka, H.; Sokolowska, P.; Cieslinska, A.; Nowacki, A.; Jaskiewicz, M.; Kamysz, W.; Liberek, B. Diosgenyl 2-Amino-2-Deoxy-Beta-D-Galactopyranoside: Synthesis, Derivatives and Antimicrobial Activity. Beilstein J. Org. Chem. 2017, 13, 2310-2315. [CrossRef] [PubMed]

123. Gu, G.F.; An, L.; Fang, M.; Guo, Z.W. Efficient One-Pot Synthesis of Tigogenin Saponins and Their Antitumor Activities. Carbohydr. Res. 2014, 383, 21-26. [CrossRef]

124. Bovicelli, P.; Lupattelli, P.; Fracassi, D.; Mincione, E. Sapogenins and Dimethyldioxirane-A New Entry to Cholestanes Functionalized at the Side-Chain. Tetrahedron Lett. 1994, 35, 935-938. [CrossRef]

125. Cheng, M.S.; Wang, Q.L.; Tian, Q.; Song, H.Y.; Liu, Y.X.; Li, Q.; Xu, X.; Miao, H.D.; Yao, X.S.; Yang, Z. Total Synthesis of Methyl Protodioscin: A Potent Agent with Antitumor Activity. J. Org. Chem. 2003, 68, 3658-3662. [CrossRef]

126. Guan, Y.Y.; Zheng, D.; Yan, Z.; Wang, N.; Lei, P.S. Synthesis and Antitumor Activity of 5,6-Dihydro-17-Hydroxy Icogenin Analogs. Eur. J. Med. Chem. 2012, 51, 200-205. [CrossRef]

127. Yu, B.; Liao, J.C.; Zhang, J.B.; Hui, Y.Z. The First Synthetic Route to Furostan Saponins. Tetrahedron Lett. 2001, 42, 77-79. [CrossRef]

128. Somberg, J.C.; Mudge, G.H.; Smith, T.W. Therapeutic and Toxic Effects of Charged Digitalis Derivatives. Circulation 1978, 58, 22.

129. Paula, S.; Tabet, M.R.; Ball, W.J. Interactions between Cardiac Glycosides and Sodium/Potassium-Atpase: Three-Dimensional Structure-Activity Relationship Models for Ligand Binding to the E-2-P-I Form of the Enzyme Versus Activity Inhibition. Biochemistry 2005, 44, 498-510. [CrossRef]

130. Menger, L.; Vacchelli, E.; Adjemian, S.; Martins, I.; Ma, Y.T.; Shen, S.S.; Yamazaki, T.; Sukkurwala, A.Q.; Michaud, M.; Mignot, G.; et al. Cardiac Glycosides Exert Anticancer Effects by Inducing Immunogenic Cell Death. Sci. Transl. Med. 2012, 4, 143ra199. [CrossRef]

131. Apetoh, L.; Ghiringhelli, F.; Tesniere, A.; Criollo, A.; Ortiz, C.; Lidereau, R.; Mariette, C.; Chaput, N.; Mira, J.P.; Delaloge, S.; et al. The Interaction between Hmgb1 and Tlr4 Dictates the Outcome of Anticancer Chemotherapy and Radiotherapy. Immunol. Rev. 2007, 220, 47-59. [CrossRef] [PubMed]

132. Michaud, M.; Martins, I.; Sukkurwala, A.Q.; Adjemian, S.; Ma, Y.T.; Pellegatti, P.; Shen, S.S.; Kepp, O.; Scoazec, M.; Mignot, G.; et al. Autophagy-Dependent Anticancer Immune Responses Induced by Chemotherapeutic Agents in Mice. Science 2011, 334, 1573-1577. [CrossRef]

133. Senovilla, L.; Vitale, I.; Martins, I.; Tailler, M.; Pailleret, C.; Michaud, M.; Galluzzi, L.; Adjemian, S.; Kepp, O.; Niso-Santano, M.; et al. An Immunosurveillance Mechanism Controls Cancer Cell Ploidy. Science 2012, 337, 1678-1684. [CrossRef] [PubMed]

134. Menger, L.; Vacchelli, E.; Kepp, O.; Eggermont, A.; Tartour, E.; Zitvogel, L.; Kroemer, G.; Galluzzi, L. Trial Watch Cardiac Glycosides and Cancer Therapy. Oncoimmunology 2013, 2, e23082. [CrossRef] [PubMed]

135. Wang, D.D.; Li, X.S.; Bao, Y.Z.; Liu, J.; Zhang, X.K.; Yao, X.S.; Sun, X.L.; Tang, J.S. Synthesis of Meon-Neoglycosides of Digoxigenin with 6-Deoxy- and 2,6-Dideoxy-D-Glucose Derivatives and Their Anticancer Activity. Bioorg. Med. Chem. Lett. 2017, 27, 3359-3364. [CrossRef] [PubMed] 
136. Tian, D.M.; Qiao, J.; Bao, Y.Z.; Liu, J.; Zhang, X.K.; Sun, X.L.; Zhang, Y.W.; Yao, X.S.; Tang, J.S. Design and Synthesis of Biotinylated Cardiac Glycosides for Probing Nur77 Protein Inducting Pathway. Bioorg. Med. Chem. Lett. 2019, 29, 707-712. [CrossRef] [PubMed]

137. Ren, Y.L.; Ribas, H.T.; Heath, K.; Wu, S.J.; Ren, J.H.; Shriwas, P.; Chen, X.Z.; Johnson, M.E.; Cheng, X.L.; Burdette, J.E.; et al. $\mathrm{Na}^{+} / \mathrm{K}^{+}$-Atpase-Targeted Cytotoxicity of (+)-Digoxin and Several Semisynthetic Derivatives. J. Nat. Prod. 2020, 83, 638-648. [CrossRef]

Publisher's Note: MDPI stays neutral with regard to jurisdictional claims in published maps and institutional affiliations.

(C) 2020 by the authors. Licensee MDPI, Basel, Switzerland. This article is an open access article distributed under the terms and conditions of the Creative Commons Attribution (CC BY) license (http://creativecommons.org/licenses/by/4.0/). 